\title{
Uso de alimentos comerciales en el levante de tortugas carey (Eretmochelys imbricata, Cheloniidae)
}

\section{Use of commercial foods in the headstarting of hawksbill turtles (Eretmochelys imbricata, Cheloniidae)}

\author{
Ricardo Andrés Sarmiento-Devia, Guiomar Aminta Jaúregui-Romero and Adolfo Sanjuan-Muñoz \\ iD $0000-0001-5264-3348 \quad$ iD $0000-0003-1239-7933 \quad$ Do000-0002-4786-862X
}

Grupo de investigación Dinámica y Manejo de Ecosistemas Marinos Costeros, Programa de Biología Marina, Facultad de Ciencias Naturales e Ingeniería, Universidad de Bogotá Jorge Tadeo Lozano, Carrera 2 \# 11-68 Edificio Mundo Marino El Rodadero, Santa Marta, Colombia. sarmientoricardo20@yahoo. es.aminta.jauregui@utadeo.edu.co; adolfo.sanjuan@utadeo.edu.co

*corresponding author

\section{RESUMEN}

$\mathrm{E}$ 1 levante o headstarting es una estrategia de recuperación para poblaciones de tortugas marinas donde los neonatos son mantenidos en cautiverio por períodos de unos pocos meses hasta alrededor de un año de edad. Para ello, los nidos son transferidos desde playas de anidación, con porcentajes bajos de éxito de eclosión, hasta viveros controlados; o los neonatos son colectados al momento de la eclosión para su traslado a acuarios. Abastecer a las tortuguillas de dietas nutricionalmente adecuadas es fundamental para asegurar su óptimo desarrollo en cautiverio. Sin embargo, conlleva costos económicos muy elevados. En este estudio se evaluó el efecto de dos alimentos de uso común en acuicultura en el crecimiento de juveniles de tortuga carey (Eretmochelys imbricata), alimentadas a saciedad dos veces al día, entre el sexto y décimo mes de edad. Los individuos alimentados con un concentrado con base en harina de pescado $(n=20)$, exhibieron una masa corporal promedio y tasas de crecimiento en talla (largo recto del caparazón recto, SCL) de $2.45 \pm 1.39$ g.día ${ }^{-1}$ y $0.04 \pm 0.02 \mathrm{~cm}$ día $^{-1}$, respectivamente. Las tortugas alimentadas con un pellet a base de harina de calamar $(\mathrm{n}=13)$, mostraron tasas de crecimiento de $3.35 \pm 1.11 \mathrm{~g}$. día ${ }^{-1}$ y $0.04 \pm 0,01 \mathrm{~cm}$. día $^{-1}$. Las diferencias observadas son relacionadas con la poca avidez de los especímenes por estos alimentos, a su vez, relacionadas con sus características físicas, en particular, el tamaño, la capacidad de flotación y la palatabilidad de los granos. Sin embargo, la presencia de aminoácidos esenciales y vitaminas en estos compuestos, junto a su bajo costo, permiten sugerir el uso de alimentos comerciales como un suplemento complementario en la dieta de tortugas marinas en cautiverio.

PALABRAS CLAVE: Alimentación artificial, Cautiverio, Comidas comerciales, Tortugas marinas, Tasas de crecimiento en talla y peso corporal.

\begin{abstract}
$\mathrm{H}$

eadstarting is a recovery strategy for sea turtle populations. It requires captive handling of hatchlings, which are transferred from nesting beaches with low percentages of hatching success. Providing adequate nutritional resources for hatchlings is costly but important, as it influences growth rates of young turtles. Assessing the potential of commercial diets as option for promoting healthy growth and reducing the costs of maintenance for captive Hawksbill Turtles, we evaluated the viability of two commercial feeds on the growth rates of the Hawksbill Turtle (Eretmochelys imbricata). We fed turtles to satiation twice a day between the sixth and tenth month of age. Individuals fed with fish flour meal $(n=20)$ exhibited average body mass and straight carapace length (SCL) growth rates of $2.45 \pm 1.39$ g.day ${ }^{-1}$ and $0.04 \pm 0.02$ $\mathrm{cm}$.day ${ }^{-1}$, respectively. The turtles fed with squid flour meal $(n=13)$ displayed growth rates of $3.35 \pm 1.11 \mathrm{~g}^{-d a y}{ }^{-1}$ and $0.04 \pm 0.01 \mathrm{~cm} . \mathrm{day}^{-1}$. These differences, associated with the low avidity of the specimens for these pellets, may be due to the food characteristics, particularly the size, flotation capability and palatability of the food. However, the presence of amino acids and vitamins in these compounds, and their low cost, can make them viable as a supplementary item suggesting the use of commercial foods only as a dietary supplement.
\end{abstract}

KEYWORDS: Artificial feeding, Captivity, Commercial meals, Sea turtles, Size and body mass rates of growth.

DOI: 10.25268/bimc.invemar.2018.47.2.751

Publicado por INVEMAR 


\section{INTRODUCCIÓN}

Las tortugas carey (Eretmochelys imbricata) están clasificadas como especies en peligro crítico por la Unión Internacional para la Conservación de la Naturaleza (UICN). Las revisiones de las tendencias en las playas de anidación de la región del Caribe en las décadas anteriores han mostrado el pequeño tamaño de la población (>100 hembras anidantes por país) y las tendencias generales de reducción en la actividad de anidación (Meylan, 1999). Las estimaciones basadas en los controles cruzados de información sobre el comercio de productos del caparazón de tortuga y la actividad reproductiva en las playas de anidación muestran que las poblaciones del Caribe continúan disminuyendo (McClenachan et al., 2006; Wyneken et al., 2013). Múltiples factores antropogénicos (por ejemplo, la iluminación) también continúan impactando el éxito reproductivo de las tortugas (Harewood y Horrocks, 2008). La desaparición de las tortugas carey en varios ecosistemas ha provocado cambios profundos en la estructura y biodiversidad de los arrecifes de coral (McClenachan et al., 2006).

La cría en cautiverio es una estrategia experimental de conservación que tiene como objetivo promover el reclutamiento de las poblaciones de tortugas marinas manteniéndolas durante los primeros meses o años, hasta que alcancen un tamaño que les permita enfrentarse con éxito a las fuentes de mortalidad natural (Mortimer, 1995; Ross, 1999; Burke, 2015). En cautiverio, las tortugas tienen acceso a una mayor cantidad de alimento y de más alta calidad nutricional; además, gastan menos energía en enfrentarse a los depredadores, las olas o los cambios de temperatura. Esto conduce a tasas de crecimiento más rápidas y quizás a una edad más temprana de madurez sexual (Bjorndal et al., 2013b). Cuando las tortugas criadas en cautiverio son liberadas en el medio marino, a pesar de haber estado en contacto constante con seres humanos durante meses o años, muestran el comportamiento típico de las tortugas salvajes (Nagelkerken et al., 2003; Monterrosa y Salazar, 2005). Las tortugas carey criadas en cautiverio pueden presentar comportamientos de migración o descanso que difieren de los de las tortugas silvestres, aunque estas habilidades podrían mejorar con algún enriquecimiento ambiental durante el período de cautiverio. (Okuyama et al., 2010). Estudios recientes de monitoreo por telemetría han demostrado que una vez liberadas, las tortugas carey pueden migrar hacia zonas de alimentación típica, utilizando las rutas naturales (PabónAldana et al., 2012). Además de promover la supervivencia de las tortugas en las etapas tempranas de la vida, el levante

\section{INTRODUCTION}

Hawksbill Turtles (Eretmochelys imbricata) are listed as a critically endangered species by the International Union for Conservation of Nature (IUCN). Reviews of the trends on the nesting beaches of the Caribbean region in previous decades showed the small size of the population (>100 nesting females per country) and the overall reduction trends in nesting activity (Meylan, 1999). Estimates based on information crosschecks of trade in turtle shell products and reproductive activity on the nesting beaches show that the Caribbean populations continue to decline (McClenachan et al., 2006; Wyneken et al., 2013). Multiple anthropogenic factors (e.g., lighting) also continue to impact the turtles' reproductive success (Harewood and Horrocks, 2008). The disappearance of Hawksbill Turtles in several ecosystems has caused deep changes in the structure and biodiversity of coral reefs (McClenachan et al., 2006).

Headstarting is an experimental conservation strategy aimed at promoting recruitment in populations of sea turtles by maintaining hatchlings in captivity during the first months or years, until they reach sizes that allow them to successfully face sources of natural mortality (Mortimer, 1995; Ross, 1999; Burke, 2015). In captivity, turtles have access to higher nutritional quality and bigger amounts of food; In addition, they spend less energy on facing predators, waves or temperature changes. This leads to faster growth rates and perhaps to an earlier age of sexual maturity (Bjorndal et al., 2013b). Once headstarted turtles are released into the marine environment, despite having been in constant contact with humans for months or years, they display the typical behavior of wild turtles (Nagelkerken et al., 2003; Monterrosa and Salazar, 2005). Head-started Hawksbills can deploy migration or resting behaviors that differ from those of wild turtles, although these abilities might be improved by some environmental enrichment during the period of captivity (Okuyama et al., 2010). Recent studies of telemetry monitoring have demonstrated that once released, head-started Hawksbills can migrate to typical feeding areas, using natural routes (Pabón-Aldana et al., 2012). In addition to promoting the turtles' survival in early life stages, headstarting programs can encourage human awareness, especially among young people, about environmental issues and the importance of biodiversity. 
puede servir como mecanismo de sensibilización de las personas, especialmente entre los jóvenes, alrededor de los problemas ambientales y la importancia de la conservación de la biodiversidad. En el levante, la alimentación de los animales constituye uno de los principales costos (Pelegrín y Fraga, 2002). Idealmente, la dieta imitará a la presa natural y aportará los elementos nutricionales necesarios para un desarrollo corporal adecuado; por ejemplo, una dieta debe asegurar un funcionamiento fisiológico, una buena salud y las tasas de crecimiento suficientes para proporcionar una ventaja ambiental (Espinosa y Labarta, 1987). Para las tortugas carey -una especie oportunista con preferencia por los corales y las esponjas (León y Bjorndal, 2002)- desarrollar una dieta completa representa un gran desafío. Como el levante requiere una gran inversión financiera, los elementos de la dieta de una especie en cautiverio deben tener costos aceptables y estar disponibles localmente.

Las granjas y centros de investigación que albergan tortugas marinas (E. imbricata, Lepidochelys olivacea, Caretta caretta, y Chelonia mydas) han alimentado a las tortugas con dietas a base de músculo de pescado (Gutiérrez y Cabrera, 1996; Mann et al., 2000a), pescado fresco, verduras (Kanghae et al., 2014), plantas rastreras de playa, macroalgas (Mann et al., 2000b), o calamar (Moein et al., 2003). En los criaderos de Nagoya (Japan), las hembras de C. caretta son alimentadas tres veces por semana con carne de pescado, camarones, calamares, col china y macroalgas, en una cantidad equivalente a $0.5 \%$ de su masa corporal (Kakizoe et al., 2013).

La dieta de dichas crías también incluye alimentos artificiales producidos por la aglomeración mecánica y compactación de mezclas (Tacon, 1989) diseñadas específicamente para las tortugas marinas u otros reptiles (Endres et al., 2012; Kanghae et al., 2014). El uso de dietas artificiales permite la selección de requisitos nutricionales específicos para las tortugas y la promoción de tasas de crecimiento rápidas con una condición corporal saludable. Los fabricantes de piensos comerciales mezclan varias fuentes de proteínas para crear dietas con un espectro equilibrado de aminoácidos y porciones de proteína con alto valor nutricional (Kellems y Church, 2002). Además, el uso de alimentos procesados facilita el mantenimiento de la calidad del agua en los sistemas de estanques con filtración y recirculación, lo que lleva a costos logísticos reducidos.

Varios estudios han intentado establecer las condiciones óptimas para la formulación de dietas artificiales (Kanghae et al., 2014). Con juveniles de C. mydas, Wood y Wood (1981) hallaron que la digestibilidad de la dieta aumenta
In headstarting, feeding animals constitutes one of the major costs (Pelegrín and Fraga, 2002). The diet ideally should mimic the natural prey and offer the nutritional requirements for proper body development; for example, a diet should ensure proper physiological functioning, good health, and sufficient growth rates to provide an environmental advantage (Espinosa and Labarta, 1987). For Hawksbill Turtles, an opportunistic species with a preference for corals and sponges (León and Bjorndal, 2002), developing a complete diet represents a major challenge. As headstarting requires a large financial investment, the elements of the diet of a species in captivity must present acceptable costs and be locally available.

Headstarting farms and research centers that house sea turtles (E. imbricata, Lepidochelys olivacea, Caretta caretta, and Chelonia mydas) have fed turtles with diets made of fish muscle (Gutiérrez and Cabrera, 1996; Mann et al., 2000a), fresh fish, vegetables (Kanghae et al., 2014), creeping beach plants, macroalgae (Mann et al., 2000b), or squid (Moein et al., 2003). In captive breeding sites in Nagoya (Japan), C. caretta females are fed three times per week with fish flesh, shrimp, squid, and Chinese cabbage as well as macroalgae, in an amount equivalent to $0.5 \%$ of their body mass (Kakizoe et al., 2013).

The diet of hatchlings in captivity has also included artificial foods that are produced by mechanical agglomeration and the compaction of mixtures (Tacon, 1989) designed specifically for sea turtles or other reptiles (Endres et al., 2012; Kanghae et al., 2014). The use of artificial diets allows the targeting of specific nutritional requirements for turtles and the promotion of fast growth rates and healthy body condition. Commercial feed manufacturers mix several protein sources to create diets with a balanced amino acid spectrum and portions of protein of high nutritional value (Kellems and Church, 2002). Also, the use of processed foods facilitates the maintenance of water quality in filtered and recirculating pond systems, which leads to reduced logistic costs.

Several studies have attempted to establish optimal conditions for the formulation of artificial diets (Kanghae et al., 2014). With juvenile C. mydas, Wood and Wood (1981) found that the digestibility of the diet increases with protein concentration and they suggested that turtles should be fed with food containing a minimum of $40 \%$ protein, at least until reaching 14 weeks of 
con la concentración de proteínas y sugirieron que los alimentos deben contener un mínimo de $40 \%$ de proteína, al menos hasta alcanzar las 14 semanas de edad. De forma similar, Harfush et al. (2000) recomiendan que las dietas para L. olivacea contengan mezclas de carne de pescado, cabezas de camarón y carne enriquecida (dextrina). Por su parte, para C. caretta, Monterrosa y Salazar (2005) compararon dietas formuladas con diferentes concentraciones de proteína, y obtuvieron los valores más altos de tasas de crecimiento utilizando niveles de proteína superiores a $40 \%$. Se obtuvieron resultados similares en pruebas para E. imbricata donde la harina de calamar, en comparación con otras fuentes de proteína, mostró los mejores efectos sobre las tasas de crecimiento y desarrollo (Pelegrín et al., 2006).

Otros estudios se han centrado en probar los efectos del enriquecimiento de las dietas artificiales. Pelegrín y Fraga (2002) descubrieron que alternar el consumo de proteína fresca con pellets de alimento, mejora el desarrollo corporal de los individuos; la inclusión de material vegetal (por ejemplo, Sargassum sp.) entre comidas también muestra beneficios relacionados con el aumento del apetito y los hábitos oportunistas de las tortugas (Mann et al., 2000a). De manera similar, Joya y Molina (2006) concluyeron que una dieta basada en proteínas de origen animal presenta mayor palatabilidad que si se basara en proteínas vegetales (p. ej., soya), a pesar de tener una composición nutricional similar. La mejora de la palatabilidad facilita el consumo de los pellets por parte de las tortugas y también influye en su asimilación.

Estudios recientes con tortugas marinas juveniles en cautiverio han usado dietas comerciales (por ejemplo, Turtle Chow), diseñadas específicamente para las tortugas (ver Endres et al., 2012). En algunos casos, las dietas artificiales han sido complementadas con suplementos dietéticos, carne de camarón, gelatinas o preparaciones caseras en las que las verduras (espinacas y lechuga), el hígado (cocido) y/o el aceite de pescado se mezclan con las vitaminas A, D, E y los complejos B (Mann et al., 2000a). Las dietas comerciales para tortugas tienen costos elevados y su disponibilidad es limitada para los países en desarrollo debido al costo de importación desde los países productores, pero hay otros alimentos procesados disponibles. Aunque estas dietas artificiales no están formuladas específicamente para tortugas marinas, pueden cumplir con los requisitos establecidos para el mantenimiento de estas especies.

Se evalúan en este estudio los efectos producidos en las tasas de crecimiento al utilizar dos dietas de alimentación comercial, originalmente diseñadas para otras especies como el camarón. (Litopenaeus vannamei) y la tilapia (Oreochromis age. Similarly, Harfush et al. (2000) recommended that diets for L. olivacea containing mixtures of fish meat, shrimp heads and enriched meat (dextrin). For C. caretta, Monterrosa and Salazar (2005) compared diets formulated with different concentrations of protein and obtained the highest values of growth rates using protein levels above $40 \%$. Similar results were obtained in tests for $E$. imbricata where squid meal, compared with other sources of protein, showed the best effects on growth rates and development (Pelegrín et al., 2006).

Other studies have focused on testing the effects of enriching the artificial diets. Pelegrín and Fraga (2002) found that alternating the consumption of fresh protein with feed pellets improves the corporal development of the individuals; including plant material (e.g., Sargassum sp.) between meals also has benefits related to the increased appetite and to the opportunistic habits of the turtles (Mann et al., 2000a). Similarly, Joya and Molina (2006) concluded that a diet based on animal protein presents greater palatability than a diet based on vegetable protein (e.g., soy), despite having a similar nutritional composition. Improved palatability facilitates the consumption of the pellets by the turtles and also influences their assimilation.

Recent studies with juvenile sea turtles in captivity used commercial diets (e.g., Turtle Chow), designed specifically for turtles (see Endres et al., 2012). In some cases, artificial diets have been complemented by dietary supplements, shrimp meat, jellies, or homemade preparations in which vegetables (spinach and lettuce), liver (cooked) and/or fish oil are mixed with A, D, E and B vitamin complexes (Mann et al., 2000a). Commercial diets for turtles have high costs and limited availability for developing countries because of the cost of importation from producer countries but other processed foods are available. Although not specifically formulated for marine turtles, these artificial diets may fulfill the requirements established for the maintenance of these species.

We evaluated the effects on growth rates produced by feeding two commercial diets, originally designed for commercial species such as shrimp (Litopenaeus vannamei) and tilapia (Oreochromis sp.), as exclusive diet in the headstarting of E. imbricata hatchlings between their sixth and tenth month of life. The effects of the diets on condition factors and animal welfare were also analyzed. Our goal was to determine whether these commercial diets are a suitable option 
sp.), como dieta exclusiva en la cría en cautiverio de las crías de E. imbricata entre el sexto y décimo mes de vida. También se analizaron los efectos de las dietas sobre los factores de condición de los individuos. El objetivo fue determinar si estas dietas comerciales son una opción adecuada para promover un crecimiento saludable y reducir los costos de mantenimiento de las tortugas carey en cautiverio.

\section{MATERIALES Y MÉTODOS}

\section{Animales y Sistemas de Mantenimiento}

Durante los últimos años, los nidos de tortugas marinas en el Parque Nacional Natural Tayrona (Caribe colombiano) han sido monitoreados $\mathrm{y}$ protegidos por voluntarios o guardaparques con el apoyo académico del Acuario Mundo Marino de la Universidad Jorge Tadeo Lozano (Santa Marta, Colombia). Cuando existe un riesgo inminente de pérdida de nidos debido a inundaciones u otras causas, los nidos se trasladan a un criadero artificial hasta la eclosión, utilizando procedimientos estándar (Wood y Wood, 1979; Mortimer, 1999). Luego, las crías se mantienen en cautiverio por períodos de aproximadamente un año, lo que permite tener tiempo para estudiar las condiciones adecuadas para el manejo de tortugas marinas en cautiverio y el desarrollo de programas de concienciación ambiental para la comunidad local.

Durante la temporada de anidación de 2006, un nido de tortugas carey procedente de la playa principal del sector Arrecifes (11 $\left.20^{\prime} 15^{\prime \prime} \mathrm{N}-73^{\circ} 58^{\prime} 44^{\prime \prime} \mathrm{O}\right)$ se reubicó en el criadero 45 días después de la oviposición. Los neonatos de tortuga ( $n=92$, éxito de eclosión $85.7 \%$, incubación 62 días) se mantuvieron en estanques de 5001 al aire libre con una densidad de 30-31 individuos por estanque con cambios diarios (siempre que fue posible) de agua y se expusieron a 12 $\mathrm{h}$ luz/12 h oscuridad, de acuerdo con el ciclo circadiano local. Además, se usó un tanque de fibra cubierto con una capacidad de $8.94 \mathrm{~m}^{3}$ (8940 1), un área de $8.13 \mathrm{~m}^{2}$ y que disponía de un mecanismo de filtración físico-químico-biológico para el mantenimiento de la calidad del agua; subdividido en dos o tres secciones mediante barreras móviles de red de plástico.

Las tortugas se mantuvieron en agua a una temperatura aproximada de $25{ }^{\circ} \mathrm{C}$, salinidad de 39.2-39.7 y un $\mathrm{pH}$ promedio de $8.05 \pm 0.33$, condiciones adecuadas para el mantenimiento de especies acuáticas en un sistema cerrado de una zona tropical (Adey y Loveland, 2007). El agua se obtuvo en la bahía de Gaira (Santa Marta, Colombia), la cual presenta un patrón de circulación en superficie que permite el recambio constante de las aguas dentro de la bahía for promoting healthy growth and reducing the costs of maintenance for captive Hawksbill Turtles.

\section{MATERIALS AND METHODS}

\section{Animals and Maintenance Systems}

For the past several years, sea turtle nests at Tayrona National Natural Park (Colombian Caribbean) have been monitored and protected by volunteers or park rangers with the academic support of the Acuario Mundo Marino from the Universidad Jorge Tadeo Lozano (Santa Marta, Colombia). When there is imminent risk of nest loss due to flooding or other causes, the nests are moved to an artificial hatchery until hatching, using standard procedures (Wood and Wood, 1979; Mortimer, 1999). Then, the hatchlings are maintained in captivity for periods of approximately one year, which allows time for studies of the proper conditions for the handling of captive sea turtles and programs of environmental awareness for the local community.

During the 2006 nesting season, a Hawksbill nest on the main beach of the Arrecifes Sector (11 $21^{\circ}$ ' 15" $\left.\mathrm{N}-73^{\circ} 58^{\prime} 44^{\prime \prime} \mathrm{W}\right)$ was relocated to the hatchery 45 days after oviposition. The turtle neonates $(\mathrm{n}=92$, hatchling success $85.7 \%$, incubation 62 days) were kept in outdoor $500 \mathrm{~L}$ ponds at a density of 30-31 individuals per pond with daily changes (always that was possible) of water and exposed to $12 \mathrm{~h}$ light $/ 12 \mathrm{~h}$ night, based on the local circadian cycle. Also, a covered trefoil fiberglass tank with an 8.94 $\mathrm{m}^{3}(8940 \mathrm{~L})$ capacity, an area of $8.13 \mathrm{~m}^{2}$, and a physicalchemical-biological filtration mechanism was used for the maintenance water quality, subdivided into two or three sections by mobile plastic net barriers.

The turtles were maintained in water at a temperature of approximately $25^{\circ} \mathrm{C}$, salinity of $39.2-39.7$, and average $\mathrm{pH}$ of $8.05 \pm 0.33$, conditions suitable for the maintenance of aquatic species in a closed system in a tropical area (Adey and Loveland, 2007). The water was collected from Gaira Bay (Santa Marta, Colombia), which presents a pattern of surface circulation that allows the waters inside the bay to be constantly changed (FrancoHerrera, 2005). The system (tank, surfaces, and accessory structures) was periodically disinfected with commercial sodium hypochlorite and abundant fresh water.

Starting on the sixth day after hatching, we fed turtles twice daily ad libitum with fish muscle from regional species such as: Opisthonema oglinum, Mugil incilis, Scomberomorus brasiliensis, Ocyurus chrysurus 
(Franco-Herrera, 2005). El sistema (tanque, superficies y estructuras accesorias) se desinfectó periódicamente con hipoclorito de sodio comercial y abundante agua fresca.

Comenzando al sexto día después de la eclosión se alimentó a las tortugas dos veces al día ad libitum con músculo de pescado de especies regionales como: Opisthonema oglinum, Mugil incilis, Scomberomorus brasiliensis, Ocyurus chrysurus y Sicydium sp. y, ocasionalmente, camarones (Litopenaeus vannamei), calamares (Loligo sp.) y cangrejos (Callinectes sp.). Estas condiciones se mantuvieron hasta el quinto mes de edad (172 días después de la eclosión), cuando la nidada $(n=92)$ se dividió en dos grupos, con 46 individuos por grupo, para evaluar los efectos de los dos tipos de alimentos comerciales.

Al comienzo del experimento, los individuos tenían un tamaño medio de $12.5 \pm 0.1 \mathrm{~cm}$ de longitud recta del caparazón (LRC) y una masa corporal de $305.14 \pm$ 54.68 g. No se registró la temperatura de incubación de la incubación que hubiera permitido estimar la proporción de sexos de las tortugas en el estudio; el sexo de los individuos no se consideró bajo el supuesto de que no hay diferencias morfométricas entre las tortugas marinas juveniles masculinas y femeninas (Kilic y Candan, 2014).

\section{Morfometría}

Para estimar el crecimiento de los especímenes durante el experimento, se midió la longitud recta del caparazón (LRC; Bolten, 1999) cada 10-16 días con una precisión de $0.1 \mathrm{~cm}$, mientras que el peso de cada espécimen se registró usando una balanza semianalítica digital (precisión de $0.01 \mathrm{~g}$ y capacidad máxima de $4000 \mathrm{~g}$ ). Anteriormente, en el quinto mes de edad, se fijó un número de dos dígitos $(00,01,02 \ldots 92)$ en la segunda placa costal de cada individuo con fines de identificación. Los números fueron grabados sobre las capas superficiales de la placa usando un mini taladro eléctrico de percusión vibratoria $(110 \mathrm{~V})$ con una fresa de carburo (Discover - China).

\section{Dietas experimentales}

Para este estudio se utilizaron dos dietas comerciales con composición y concentración similar de vitaminas (Tabla 1), introduciendo estos pellets en la dieta de las tortugas a los cinco meses de edad (d 172 post-eclosión). El alimento A es una dieta ampliamente utilizada en la crianza de tilapia juvenil (Oreochromis sp.) en alta densidad. Consistía en partículas esféricas de color marrón claro (2.3 $\mathrm{mm}$ de diámetro) que flotaban en la superficie del agua y permanecían intactas and Sicydium sp. and, occasionally, shrimp (Litopenaeus vanamei), squid (Loligo sp.) and crab (Callinectes sp.). These conditions were maintained until the fifth month of age ( 172 days after hatching), when the clutch $(n=92)$ was divided into two groups, with 46 individuals per group, to evaluate the effects of the two commercial feeds.

At the beginning of the experiment, individuals had a mean size of $12.5 \pm 0.1 \mathrm{~cm}$ of straight carapace length (SCL) and a body mass of $305.14 \pm 54.68 \mathrm{~g}$. We did not record the clutch incubation temperature that would have allowed us to estimate the sex ratio of the turtles in our study; the sex of the individuals was not considered under the assumption that there are no morphometric differences between male and female juvenile sea turtles (Kilic and Candan, 2014).

\section{Morphometrics}

To estimate the growth of the specimens during the experiment, the straight carapace length (SCL; Bolten, 1999) was measured every 10-16 days with $0.1 \mathrm{~cm}$ precision, while each specimen weight was recorded using a digital semi-analytical scale $(0.01 \mathrm{~g}$ precision and maximum capacity of $4000 \mathrm{~g}$ ). Previously, at the fifth month of age, a two-digit number $(00,01,02 . .92)$ was fixed on the second costal scute of each individual for identification purposes. Numbers were carved into the surface layers of the scute using a mini electric vibro-speed drill $(110 \mathrm{~V})$ with a carbide mill (Discover - China).

\section{Experimental diets}

For this study, we tested two commercial diets with similar compositions and concentrations of vitamins (Table1), introducing these pellets into the turtles' diet at the fifth month of age (d 172 post-hatching). Food $\mathrm{A}$ is a diet widely used in rearing juvenile tilapia (Oreochromis sp.) at high density. It consisted of light brown spherical particles (2.3-mm diameter) that floated on the surface of the water and remained intact for about two hours. Food B is a supplement for marine shrimps. It consisted of thick, dark brown cylindrical grains $(4.5 \mathrm{~mm}$ length and $1.5 \mathrm{~mm}$ diameter); once in the water, those grains fell directly to the bottom, where they remained intact for long periods. Food A and Food B differed in the presence of some essential amino acids and salts (Table 1) but especially with regard to the protein source. Food A is manufactured from fishmeal, while Food B consists of squid meal. Furthermore, Food A included wheat flour as a binder, while in Food B, rice flour was used. 
durante aproximadamente dos horas. El alimento B es utilizado en el engorde de camaron. Consistía en granos cilíndricos gruesos, de color marrón oscuro (4.5 $\mathrm{mm}$ de longitud y 1.5 $\mathrm{mm}$ de diámetro); una vez en el agua, esos granos caían directamente al fondo, donde permanecían intactos durante largos períodos. El alimento A y el alimento B difirieron en la presencia de algunos aminoácidos esenciales y sales (Tabla 1), pero especialmente con respecto a la fuente de proteína. El alimento A se fabrica a partir de harina de pescado, mientras que el alimento B consiste en harina de calamar. Además, el alimento A incluía harina de trigo como aglutinante, mientras que el alimento B incluía harina de arroz.

Tabla 1. Composición, nutrientes y características de los pellets comerciales evaluados en este estudio como una dieta completa para las crías de tortuga carey. Los ingredientes que los diferencian en su composición se destacan en gris.

\begin{tabular}{|c|c|c|}
\hline Elemento / Item & Alimento A / Food A & Alimento B / Food B \\
\hline Ceniza máxima (\%) / Maximum ash (\%) & 10 & 10 \\
\hline Fibra máxima (\%) / Maximum Fiber (\%) & 6 & 4 \\
\hline Bajo en grasa $(\%) /$ Low fat $(\%)$ & 4 & 6 \\
\hline Humedad máxima (\%) / Maximum Humidity (\%) & 12 & 12 \\
\hline Bajo en proteínas (\%) / Low protein (\%) & 38 & 35 \\
\hline Aceite de soya y/o aceite de maíz / Soybean oil and/or corn oil & $\mathrm{X}$ & \\
\hline Aceite de pescado / Fish oil & $\mathrm{X}$ & $\mathrm{X}$ \\
\hline Aceite de calamar / Squid oil & & $\mathrm{X}$ \\
\hline Ácido ascórbico (antimicrobiano) / Ascorbic acid (antimicrobial) & $\mathrm{X}$ & $\mathrm{X}$ \\
\hline Ácido fólico / Folic acid & $\mathrm{X}$ & $\mathrm{X}$ \\
\hline Arroz / Rice & $\mathrm{X}$ & $\mathrm{X}$ \\
\hline Biotina / Biotin & & $\mathrm{X}$ \\
\hline $\begin{array}{l}\text { Antioxidantes BHT (2,6-di-tert-butil) -4-metifenol) oretoxiquina } \\
\text { (6-etoxi-, 1,2-dihidro-2, 2,4-trimetil-quinolina) / BHT (2,6-di- } \\
\text { tert-butyl) -4-metifenol) orethoxyquin (6-Etoxy-, 1,2-dihydro-2, } \\
\text { 2,4-trimethyl-quinoline)antioxidants }\end{array}$ & $\mathrm{X}$ & $\mathrm{X}$ \\
\hline Carbonato de calcio / Calcium carbonate & $\mathrm{X}$ & \\
\hline Cloruro de colina / Choline chloride & $\mathrm{X}$ & $\mathrm{X}$ \\
\hline Cloruro de sodio / Sodium chloride & $\mathrm{X}$ & \\
\hline Colesterol / Cholesterol & & $\mathrm{X}$ \\
\hline $\begin{array}{l}\text { Fosfato bicálcico desfluorado / Calcium phosphate bi de } \\
\text { fluorinated }\end{array}$ & $\mathrm{X}$ & \\
\hline Fosfato monosódico / Monosodium phosphate & & $\mathrm{X}$ \\
\hline Harina de calamar / Squid meal & & $\mathrm{X}$ \\
\hline Harina de pescado / Fish meal & $\mathrm{X}$ & \\
\hline Harina de carne / Meat meal & $\mathrm{X}$ & \\
\hline Lecitina / Lecitin & & $\mathrm{X}$ \\
\hline Lisina / Lisina & $\mathrm{X}$ & $\mathrm{X}$ \\
\hline Trigo/maíz molido/sorgo / Wheat/ground corn/sorghum & $\mathrm{X}$ & $\mathrm{X}$ \\
\hline Metionina / Methionine & $\mathrm{X}$ & $\mathrm{X}$ \\
\hline Niacina / Niacin & $\mathrm{X}$ & $\mathrm{X}$ \\
\hline
\end{tabular}

Table 1. Composition, nutrients, and characteristics of commercial pellets evaluated in this study as a complete diet for Hawksbill Turtle hatchlings. The ingredients that differentiate them in their composition are highlighted in gray. fish muscle offered to the complete experimental group of specimens was gradually reduced from approximately 3 $\mathrm{kg}$ day $^{-1}$ to $0 \mathrm{~kg}$ day $^{-1}$, over five days, while the portion of experimental food offered was increased. After 105 more days (i.e., 110 days total), the turtles were fed pellets twice daily, morning and afternoon. Veterinary management of dermatological and systemic diseases, without any relation to the essay, led to the removal of several individuals from the experiment. During the experiment, several individuals suffered dermic bacterial and fungal infections caused by aggressions that resulted in traumatic injuries (see Bailey,

\begin{tabular}{l|l} 
Alimento A / Food A & Alimento B / Food B
\end{tabular}

Ceniza máxima $(\%)$ / Maximum ash $(\%)$

10

$\mathrm{X}-\mathrm{s}$

Antioxidantes BHT (2,6-di-tert-butil) -4-metifenol) oretoxiquin

2,4-trimethyl-quinoline)antioxidants

Carbonato de calcio / Calcium carbonate

$\mathrm{X}$ $\mathrm{X}$

$\mathrm{X}$ 


\begin{tabular}{|c|c|c|}
\hline Elemento / Item & Alimento A / Food A & Alimento B / Food B \\
\hline Sulfato u óxido de zinc / Zinc sulfate or oxide & $\mathrm{X}$ & $\mathrm{X}$ \\
\hline Sulfato u óxido de manganeso / Manganese sulfate or oxide & $\mathrm{X}$ & $\mathrm{X}$ \\
\hline Sulfato u óxido ferroso / Ferrous sulfate or oxide & $\mathrm{X}$ & $\mathrm{X}$ \\
\hline Pantotenato de calcio / Calcium Pantothenate & $\mathrm{X}$ & $\mathrm{X}$ \\
\hline Piridoxina / Piridoxin & $\mathrm{X}$ & $\mathrm{X}$ \\
\hline Riboflavina / Riboflavin & $\mathrm{X}$ & $\mathrm{X}$ \\
\hline Sulfato de cobre / Copper sulfate & $\mathrm{X}$ & $\mathrm{X}$ \\
\hline Sulfato de magnesio / Magnesium sulfate & $\mathrm{X}$ & \\
\hline Tiamina / Thiamine & $\mathrm{X}$ & $\mathrm{X}$ \\
\hline Harina de soya / Soy bean meal & $\mathrm{X}$ & $\mathrm{X}$ \\
\hline Pastel de algodón / Cotton cake & $\mathrm{X}$ & \\
\hline Treonina / Threonine & $\mathrm{X}$ & \\
\hline Vitaminas A, B12, E, / Vitamin A, B12, E, & $\mathrm{X}$ & $\mathrm{X}$ \\
\hline Vitamina C / Vitamin C & & $\mathrm{X}$ \\
\hline Vitamina D / Vitamin D & $\mathrm{X}$ & \\
\hline Vitamina D3 / Vitamin D3 & & $\mathrm{X}$ \\
\hline Vitamina K / Vitamin K & $\mathrm{X}$ & \\
\hline $\begin{array}{l}\text { Yodato de calcio y/o dihidroioduro de etilendiamina (EDDI) / } \\
\text { Calcium iodate and/or EDDI }\end{array}$ & $\mathrm{X}$ & $\mathrm{X}$ \\
\hline $\begin{array}{l}\text { Costo (CO pesos/kg en febrero de 2007) / Cost (CO pesos/kg in } \\
\text { February 2007) }\end{array}$ & $\$ 1997.5$ & $\$ 2300.0$ \\
\hline
\end{tabular}

Para introducir los pellets en la dieta, la porción de músculo de pescado ofrecida a todo el grupo experimental de especímenes se redujo gradualmente desde aproximadamente $3 \mathrm{~kg}$ día $^{-1}$ a $0 \mathrm{~kg}$ día ${ }^{-1}$, durante cinco días, aumentando al mismo tiempo la porción de alimento experimental. Después de 105 días más (es decir, 110 días en total), las tortugas fueron alimentadas con pellets dos veces al día, por la mañana y por la tarde.

La atención veterinaria de las enfermedades dermatológicas y sistémicas, sin relación alguna con el ensayo, llevó a la separación de varios individuos del experimento, los cuales sufrieron infecciones bacterianas y micóticas dérmicas causadas por agresiones que ocasionaron lesiones traumáticas (Bailey, 2008). Este tipo de infecciones aparentemente son comunes en tortugas marinas en cautiverio, favorecidas por el hacinamiento de los sistemas cerrados, en los que aumentan los incidentes de mordeduras y las condiciones de baja calidad del agua (Sison et al., 1990; Bailey, 2008; Chuen-Im et al., 2010). En este caso, esas lesiones se trataron diariamente con la aplicación tópica de antibióticos o soluciones antisépticas (p. ej., rifampicina, povidona, tintura de yodo en dilución $1: 2$, oxitetraciclina) y "baños de sol", lo que resultó en una regeneración progresiva de las heridas. En otros casos,
2008). This kind of infections apparently are common in captive sea turtles, and are promoted by overcrowding in the closed systems, that increase biting incidents, and low water quality conditions (Sison et al., 1990; Bailey, 2008; ChuenIm et al., 2010). In this case, these injuries were treated daily with topical antibiotic or antiseptic solutions (e.g., rifampin, povidone, iodine tincture 1:2 dilution, oroxytetracycline) and "sunbaths", resulting in a progressive regeneration of the wounds. In other cases, these diseases resulted in stomatitis with a secondary bacterial infection, which led to the intravenous application of broad-spectrum antibiotics (e.g., enrofloxacin $5 \mathrm{mg} / \mathrm{kg}$ i. m. every 48 hours).

Then, those individuals given the intravenous antibiotics were removed from the experiment because of the potential effects of the veterinary treatment on the individual weight of the turtles. Thus, the estimates presented here are based on measurements made with 33 turtles divided into two groups: Food A $(n=13)$ and Food B $(n=20)$. We present estimates for the rest of the turtles fed fresh protein, here called group Fish $(n=43)$, which were not directly compared with the experimental groups after they had received veterinary treatments that included antibiotic and anti-inflammatory medicines that could 
estas enfermedades causaron estomatitis con una infección bacteriana secundaria, lo que llevó a la aplicación intravenosa de antibióticos de amplio espectro (p. ej., enrofloxacina $5 \mathrm{mg}$ / $\mathrm{kg}$ im cada 48 horas). Luego, los individuos que recibieron los antibióticos intravenosos fueron retirados del experimento debido a los efectos potenciales del tratamiento veterinario sobre el peso individual de las tortugas. Por lo tanto, las estimaciones presentadas aquí se basan en las mediciones realizadas con las 33 tortugas divididas en dos grupos: alimento A $(n=13)$ y alimento $\mathrm{B}(n=20)$. Se presentan estimaciones para el resto de las tortugas alimentadas con proteína fresca, aquí llamado grupo pescado $(n=43)$, que no se compararon directamente con los grupos experimentales después de haber recibido tratamientos veterinarios que inclúan antibióticos y medicamentos antiinflamatorios que podrían influir en su condición corporal.

El día 287 se cambiaron todas las tortugas a una dieta de músculo de pescado, algunos suplementos dietéticos, calamares y camarones. Además, antes de ser liberadas en el océano desde el sitio de anidación, 11 meses después de la eclosión, las tortugas fueron alimentadas con algas, camarones y cangrejos como alimento vivo.

\section{Factor de condición}

Con base en cada medición, se calculó el factor de condición (FC) individual de la siguiente manera:

$$
F C=\frac{M}{L R C^{b}}
$$

Donde $\mathrm{M}$ es la masa individual, LRC es la longitud recta del caparazón y b es el coeficiente de regresión para la regresión entre la altura y la masa $(b=2.6043$, LabradaMartagón et al., 2010).

\section{Tasas de crecimiento}

Para este estudio, se definió el crecimiento como la diferencia en tamaño (LRC) o masa para cada individuo durante un intervalo de tiempo específico. Con base en Bjorndal et al. (2013a) y Casale et al. (2009), la Tasa de Crecimiento en Tamaño (TCT) se estima como

$$
\mathrm{TCT}=\frac{\left(\mathrm{LRCn}_{\mathrm{t}}-L R C \mathrm{n}_{\mathrm{T}-1}\right)}{\mathrm{t}-(\mathrm{t}-1)}
$$

Donde $\mathrm{n}$ se refiere a un individuo específico, $\mathrm{LRC} n_{\mathrm{t}}$ es el tamaño de ese individuo ( $n$ ) en un momento dado ( $\mathrm{t}$ ), $\mathrm{y}$ influence their body condition.

On d 287, we switched all the turtles to a diet of fish muscle, some dietary supplements, squid and shrimp. Further, before being released into the ocean from the nesting site11 months post hatching, the turtles were fed algae, shrimps and crabs as live foods.

\section{Condition factor}

Based on every measurement, we calculated each individual condition factor $(\mathrm{CF})$ as follows:

$$
C F=\frac{M}{S C L^{b}}
$$

Where $\mathrm{M}$ is the individual mass, $\mathrm{SCL}$ is the straight carapace length, and $\mathrm{b}$ is the regression coefficient for the regression between height and mass $(b=2.6043$, LabradaMartagón et al., 2010).

\section{Growth Rates}

For this study, we define growth as the difference in size (SCL) or mass for each individual during a specific time interval. Based on Bjorndal et al. (2013a) and Casale et al. (2009), the Size Growth Rate (SGR) is estimated as

$$
S G R=\frac{\left(S C L n_{t}-D C L n_{T-1}\right)}{t-(t-1)}
$$

Where $\mathrm{n}$ refers to a specific individual, SCL $n t$ is the size of that individual $(n)$ at a given time $(\mathrm{t})$, and $\mathrm{SCL} n_{\mathrm{t}-1}$ is the size of the same individual in a previous measurement made $t$ days prior. There was a period of 10 to 16 days between each SCL measurement. Using a similar approach to that used by Sampson et al. (2015) and Pelegrín et al. (2003a), we estimated weight growth rate (WGR) as the increase in mass of the individual over time, according to the following equation:

$$
W G R=\frac{\left(W n_{t}-W n_{T-1}\right)}{t-(t-1)},
$$

Where $\mathrm{W} n_{\mathrm{t} \text { is }}$ the weight (grams) of the individual at a given time $(\mathrm{t})$, and $\mathrm{W} n_{\mathrm{t}-1}$ is the mass of the same individual at the time of the previous measurement ( $\mathrm{t}-1)$. Then, the effect of the diet on turtle WGR and SGR was estimated by a Repeated Measured ANOVA [Food: A and B; Age (days)], while normality was tested by the Shapiro-Wilk analysis, using statistics software STATISTICA 8.0 by Stat. Soft. Inc. 
$\mathrm{LRCn}_{\mathrm{t}-1}$ es el tamaño del mismo individuo en una medición previa realizada $t$ días antes. Hubo un período de 10 a 16 días entre cada medición de la LRC. Usando un enfoque similar al de Pelegrín et al. (2003a) y Sampson et al. (2015), se estimó la tasa de crecimiento en peso (TCP) como el aumento de la masa del individuo a lo largo del tiempo, de acuerdo con la siguiente ecuación:

$$
\mathrm{TCP}=\frac{\left(\mathrm{Pn}_{\mathrm{t}}-\mathrm{Pn}_{\mathrm{T}-1}\right)}{\mathrm{t}-(\mathrm{t}-1)}
$$

Donde $\mathrm{P} n_{\mathrm{t}-1}$ es el peso (gramos) del individuo en un momento dado ( $\mathrm{t}$ ), y $\mathrm{P} n_{\mathrm{t}-1}$ es el peso del mismo individuo en el momento de la medición anterior (t-1). Luego, el efecto de la dieta en la TCP y TCT de la tortuga se estimó mediante un ANOVA de medidas repetidas (alimento: A y B; Edad (días)), mientras que la normalidad se comprobó mediante el análisis de Shapiro-Wilk, utilizando el software STATISTICA 8.0 de Stat. Soft. Inc.

\section{RESULTADOS}

\section{Aceptación y consumo.}

Una vez que los alimentos experimentales fueron introducidos en la dieta, la respuesta de comportamiento varió entre los individuos. Para el grupo de alimento A, cuando las partículas se colocaron por primera vez en la superficie del agua, los postneonatos no mostraron una respuesta inmediata. Se acercaron de forma progresiva (minutos) y comieron algunos pellets. A medida que disminuía el tamaño de las porciones de músculo de pescado, aumentaba su interés por los pellets y la ingestión de los mismos. Para el alimento $\mathrm{B}$, los granos inmediatamente llamaron la atención de los especímenes cuando cayeron por la columna de agua al fondo del estanque. En respuesta, desde la primera vez que se les dio este concentrado, las tortugas se movieron hasta el punto en que cayeron los granos, los mantuvieron en la boca varias veces y finalmente los mordieron y tragaron. En este caso, el tamaño de grano facilitó el escape de los trocitos de la alimentación a través de los bordes de la mandíbula.

Cinco días después de que comenzara el ensayo, cuando se suspendió por completo el suministro de músculo de pescado y aumentó la oferta de alimentos experimentales, en general los individuos mostraron inapetencia. Luego, mostraron un aumento de la avidez, especialmente por el Alimento A. Estos granos, que flotaban en la superficie del agua, parecían llamar su

\section{RESULTS}

\section{Acceptance and consumption}

Once the experimental foods were introduced to the diet, the behavioral response varied among individuals. For group Food A, when the particles were first laid on the surface of the water, the post-hatchlings had no immediate response. Progressively (minutes), they approached and ate some grains. As the size of the fish muscle portions decreased, their interest in and ingestion of the pellets increased. For Food B, the grains immediately caught the attention of the specimens as they fell by the water column to the bottom of the pond. In response, from the first time they were given this concentrate, the turtles moved to the point where the grains fell, held them in their mouths several times and finally bit and swallowed them. In this case, the grain size made it easy for bits of the feed to escape through the jaw edges

Five days after the study started, when the fish muscle supply was completely suspended and the offer of experimental foods increased, individuals overall showed inappetence. Then, they showed an increased avidity, especially for Food A. These grains, floating on the water surface, seemed to get their attention and reduce the stress generated by the change of diet. Fortyfive days after the start of the study, grain consumption increased from $30 \mathrm{~g}$ (approx.0.7 $\mathrm{g} \mathrm{ind}^{-1} \mathrm{day}^{-1}$ ) to over $120 \mathrm{~g}$ per group. Subsequently, the supply of food was doubled even if the amount of food eaten did not seem to change. This measure was implemented to reduce anxiety and stress among individuals that attacked each other. This behavior is common in captive Hawksbill sea turtle post-hatchlings, probably due to space constraints in the tank (pers. obs.), although density conditions for this essay $\left(6.4-11.2\right.$ ind. $\left.\mathrm{m}^{-2}\right)$, were close or below those used in similar studies with captive sea turtles (See table 2).

\section{Reduction in Sample Sizes.}

During experiments, 16 (17.4\%) hatchlings died. Further, 43 became infected with ailments and were treated with full recovery. All these were removed from experimental analyses. Of the initial sample of 46 per trial, we had only 13 (28.3\%) in group A and 20 (43.5\%) in group $\mathrm{B}$ remaining for comparisons. 
atención y reducir el estrés generado por el cambio de dieta. Cuarenta y cinco días después del inicio del estudio, el consumo de grano aumentó desde $30 \mathrm{~g}$ (aprox. $0.7 \mathrm{~g}$ ind $^{-1}$ día $^{-1}$ ) a más de $120 \mathrm{~g}$ por grupo. Posteriormente, el suministro de alimentos se duplicó, aunque la cantidad de alimentos consumidos no parecía cambiar. Esta medida se implementó para reducir la ansiedad y el estrés de los individuos que llegaron a atacarse entre ellos mismos. Este comportamiento es común en las crías de tortugas carey post-eclosión, probablemente debido a limitaciones de espacio en el tanque (obs. pers.), aunque las condiciones de densidad para este ensayo $\left(6.4-11.2\right.$ ind. $\left.\mathrm{m}^{-2}\right)$, fueron cercanas o inferiores a las utilizadas en estudios similares con tortugas marinas en cautiverio (Tabla 2).
Assimilation of Food

Body Condition and Growth Rates

For this study, the condition factor presented values between 8.56 and $10.43 \times 10^{-4}$. For this variable, the group fed with Food B had the highest oscillation range, between $9.55 \times 10^{-4}(\mathrm{~d} 233)$ and $8.56 \times 10^{-4}(\mathrm{~d} 286)$.

\section{Size and Weight Growth Rates}

The size growth rate (SGR) presented values between 0.01 and $0.21 \mathrm{~cm}$. day $^{-1}$, normally distributed (Shapiro-Wilk W $=0.96, P=<0.001)$, with an average of $0.03 \pm 0.04 \mathrm{~cm} \mathrm{day}^{-1}$. The SGR values did not show a consistent trend but increased or decreased between each measurement (Figure 1).
Tabla 2. Indicadores de dietas, densidad y morfometría obtenidos para Eretmochelys imbricata en otros sistemas cerrados. $\delta^{\top}$ : machos, + : hembras; P: peso corporal; LRC: Longitud recta del caparazón; N: Neonato; J: Juvenil
Table 2. Diets, density and morphometric indicators obtained for Eretmochelys imbricata in other closed systems. ${ }^{\top}$ : males, ㅇ: females; W: body mass; SCL: Straight carapace length; N: Neonate; J: Juvenile

\begin{tabular}{|c|c|c|c|c|c|c|c|c|}
\hline $\begin{array}{l}\text { Referencia } \\
\text { Reference }\end{array}$ & n & $\begin{array}{c}\text { Edad } \\
\text { Age }\end{array}$ & $\begin{array}{l}\text { Dieta } \\
\text { Diet }\end{array}$ & $\begin{array}{l}\text { Densidad } \\
\text { Density }\end{array}$ & $\begin{array}{c}\text { TCT } \\
(\mathrm{cm} \text { día-1) } \\
\text { SGR } \\
(\mathrm{cm} \text { d }-1)\end{array}$ & $\begin{array}{c}\text { TCP } \\
\text { (g día-1) } \\
\text { WGR } \\
\text { (g day-1) }\end{array}$ & $\begin{array}{l}\text { Tamaño: Cuerpo } \\
\text { Relación de masa } \\
\text { Size: Body } \\
\text { Mass Ratio }\end{array}$ & $\begin{array}{l}\text { Mortalidad } \\
(\%) \\
\text { Mortality } \\
(\%)\end{array}$ \\
\hline $\begin{array}{c}\text { Gutiérrez } \\
\text { y Cabrera } \\
(1996)\end{array}$ & $\begin{array}{l}130 \\
70 \hat{\jmath} \\
609\end{array}$ & $\mathrm{~J}$ & $\begin{array}{c}\text { Oreochromis sp. } \\
\text { Ad libitum } \\
2 \text { veces día }^{-1} / 2 \text { timesday }\end{array}$ & $\begin{array}{l}3 \text { ind. } \mathrm{m}^{-2} \\
3 \text { ind. } \mathrm{m}^{-3}\end{array}$ & $0.043-0.045$ & $11.06 \pm 4.32$ & $\begin{array}{l}P=5.207 \times 10^{-3} \mathrm{LRC}^{3.8807} \\
W=5.207 \times 10^{-3} \mathrm{SCL}^{3.8807}\end{array}$ & 0 \\
\hline \multirow[t]{2}{*}{$\begin{array}{l}\text { Joya y } \\
\text { Molina } \\
(2006)\end{array}$} & 12 & $\mathrm{~J}$ & $\begin{array}{c}\text { Pellet (soya, } \\
38.80 \% \text { proteína) } \\
\text { Pellet (soy, } 38.80 \% \text { protein) }\end{array}$ & $\begin{array}{c}0.04 \text { ind. } \mathrm{l}^{-1} \\
\text { (hasta } 8 \text { meses / } \\
\text { until } 8 \text { months) } \\
0.02 \text { ind. } 1^{-1} \\
\text { (hasta } 1 \text { año / until } \\
\text { a year) }\end{array}$ & $\begin{array}{c}0.04-0.06 \\
0.014\end{array}$ & $0.96-6.42$ & $\begin{array}{c}P=31.439 \\
\mathrm{LRC}^{1.4039} \\
W=31.439 \mathrm{SCL}^{1.4039}\end{array}$ & 0 \\
\hline & 12 & & $\begin{array}{l}\text { Opisthonema oglinum } \\
\text { enriquecido (18.30\% } \\
\text { proteína) } \\
\text { Ad libitum } 2 \text { veces día }{ }^{-1} \\
\text { enriched(18.30\%protein) } \\
\text { Ad libitum } 2 \text { times day }{ }^{-1}\end{array}$ & & $\begin{array}{c}0.04-0.010 \\
0.014\end{array}$ & $4.37-9.34$ & & \\
\hline $\begin{array}{c}\text { Kaufmann } \\
\text { (1975) }\end{array}$ & 25 & & $\begin{array}{l}\text { Lisa blanca Mugil curema; } \\
\text { Cazón Carcharhinus } \\
\text { acronotus; Caranx latus; } \\
\text { tiburón toro Carcharhinus } \\
\quad \text { leucas. } \\
3 \text { veces día }{ }^{-1} \text { ad libitum } \\
3 \text { times day }{ }^{-1} \text { ad libitum }\end{array}$ & & 0.091 & 7.92 & & 20 \\
\hline $\begin{array}{l}\text { Pelegrín et } \\
\text { al. (2003) }\end{array}$ & 45 & $\mathrm{~N}$ & $\begin{array}{l}45 \% \text { proteína / protein } \\
47 \% \text { proteína / protein } \\
* 49 \% \text { proteína / protein } \\
\text { *51\% proteína / protein } \\
53 \% \text { proteína / protein } \\
\\
55 \% \text { proteína / protein } \\
4 \% \text { biomasa / biomass } \\
2 \text { veces } \mathrm{d}^{-1} \times 65 \text { días / } 2 \\
\text { times d } \mathrm{d}^{-1} \times 65 \text { days. }\end{array}$ & $\begin{array}{c}3 \text { ind. } 0.28 \mathrm{~m}^{-2} \\
\mathrm{O} / \text { or } \\
3 \text { ind. } 40 \mathrm{l}^{-2}\end{array}$ & & $* 2.8$ & & 0 \\
\hline
\end{tabular}




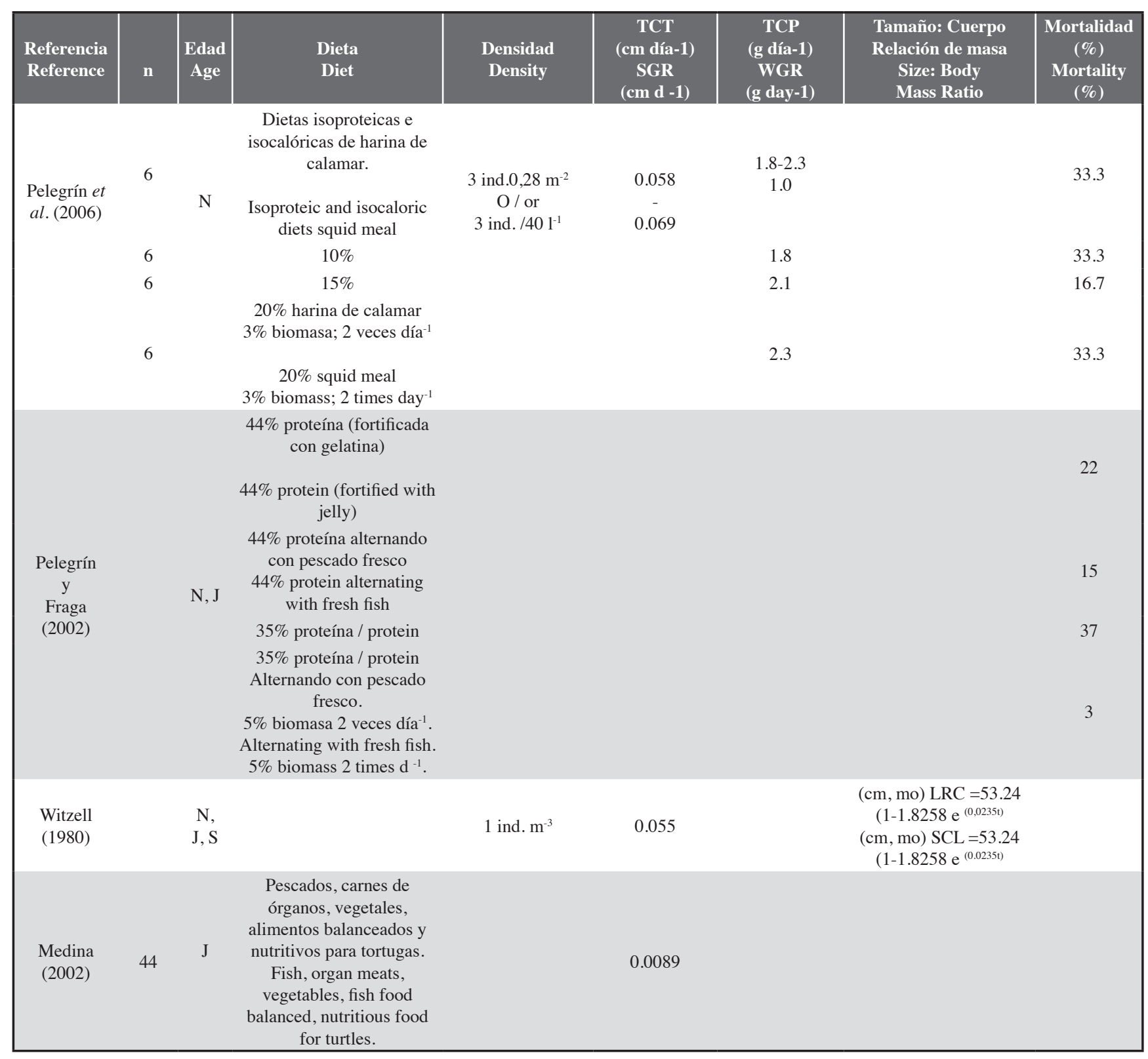

Reducción en los tamaños de la muestra.

Durante los experimentos, $16(17.4 \%)$ crías murieron. Además, 43 se infectaron con enfermedades, fueron tratadas y se recuperaron por completo. Todas éstas fueron eliminadas de los análisis experimentales. De la muestra inicial de 46 por ensayo solo se consideran 13 (28.3\%) individuos del grupo A y 20 (43.5\%) del grupo B, para las estimaciones aquí presentadas.

\section{Asimilación de los alimentos}

Condición corporal y tasas de crecimiento

Para este estudio, el factor de condición presentó valores entre 8.56 y $10.43 \times 10^{-4}$. Para esta variable, el
Further, the SGR decreased for all individuals between the second and the last measurement, as evidence of a general slowdown trend of growth when the posthatchlings approached 11 months of age (Figure 2). A Repeated Measures ANOVA test evidenced (Table 3) significant differences related to both the experimental diet and the date (age) of measuring. However, only in the case of the experimental diets did clear difference appear between the experimental groups, with those individuals fed Food B deploying a higher SGR

Weight growth rates for the experimental groups presented values between -8.37 and $14.90 \mathrm{~g} \mathrm{day}^{-1}$, normally distributed (Shapiro-Wilk $\mathrm{W}=0.987, P=0.086$ ) with an 
grupo alimentado con el Alimento $\mathrm{B}$ tuvo el rango de oscilación más alto, entre $9.55 \times 10^{-4}$ (d 233) y 8.56 x $10^{-4}(\mathrm{~d} 286)$.

Tasas de crecimiento en peso y tamaño

La tasa de crecimiento en tamaño (TCT) presentó valores entre 0.01 y $0.21 \mathrm{~cm}$. día ${ }^{-1}$, con distribución normal (Shapiro-Wilk $\mathrm{P}=0.96, P=<0.001$ ), con un promedio de $0.03 \pm 0.04 \mathrm{~cm} \mathrm{día}^{-1}$. Los valores de TCT no mostraron una tendencia constante, sino que aumentaron o disminuyeron con cada medición (Figura 1). average value of $3.4 \pm 3.4 \mathrm{~g}$ day $^{-1}$. Mean values presented significant differences between groups $(\mathrm{t}-$ Test, $\mathrm{t}$-value $=$ 2.42, $P=0.016, \mathrm{df}=193)$, being higher in the group fed Food B $\left(4.13 \pm 3.079 \mathrm{~g} \mathrm{day}^{-1}\right)$ than in the one fed Food A $\left(2.92 \pm 3.079 \mathrm{~g} \mathrm{day}^{-1}\right)$. A Repeated Measures ANOVA (Table 3) evidenced that both diet and age (i.e., date of measure) of the individuals had an effect on the WGR values, although the effect related to the diet was lower. The WGR values did not present a general trend except for an overall increase from the moment the experiment end and the complete group of turtles was fed with fresh protein.

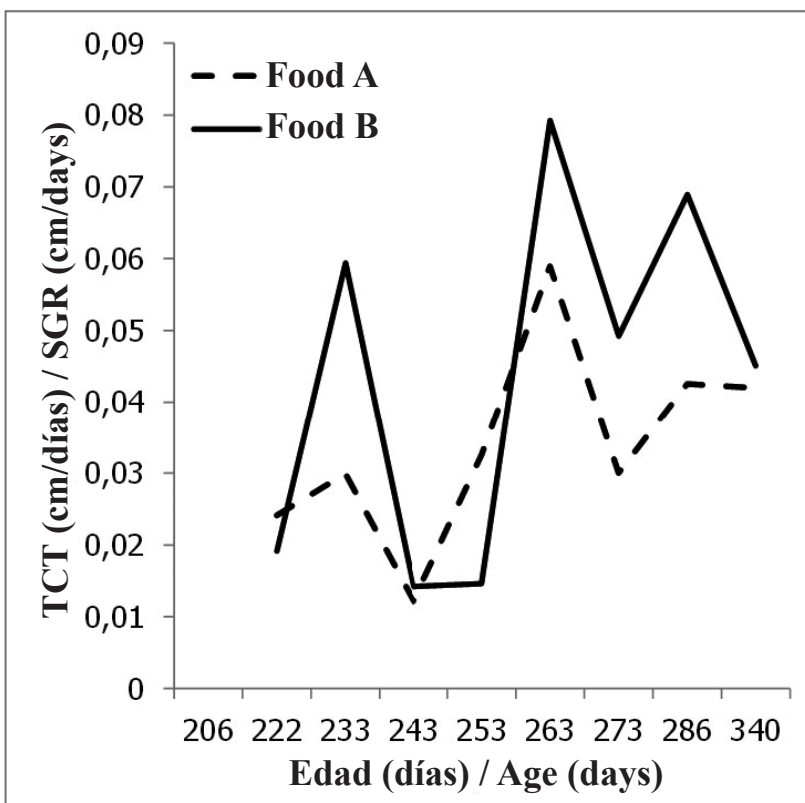

Figura 1. Tasas de crecimiento promedio en tamaño (TCT) y masa corporal (TCM) para los dos grupos experimentales (Alimento A, n: 30 individuos; Alimento B, n: 13 individuos) de juveniles de tortuga carey alimentados con dietas comerciales.

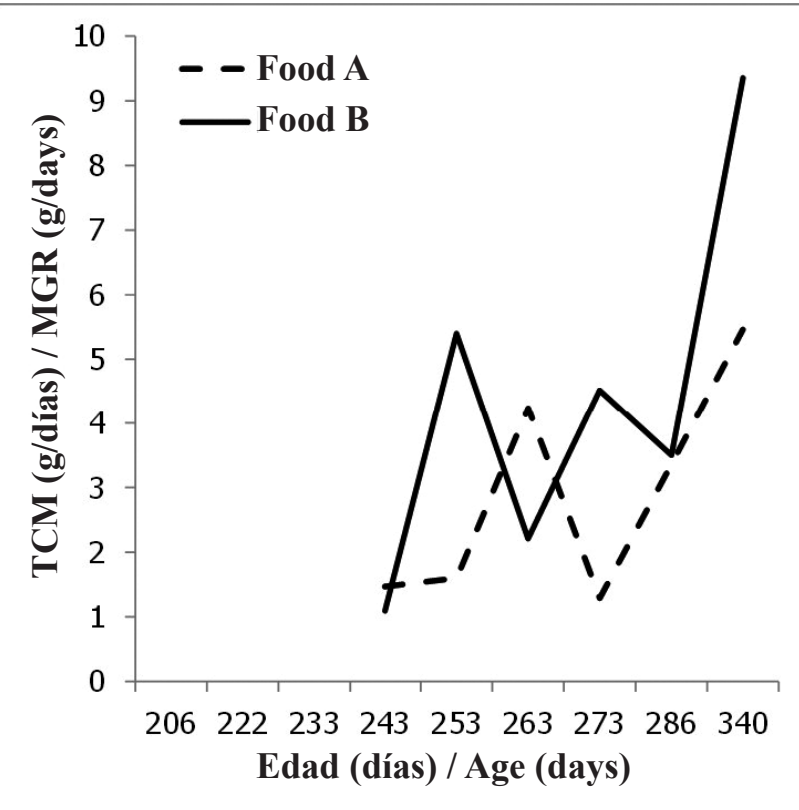

Figure 1. Average growth rates in size (SGR) and body mass (MGR) for two experimental groups (Food A, n: 30 individuals; Food B, n: 13 individuals) of Hawksbill Turtle juveniles fed with commercial diets.
Además, la TCT disminuyó para todos los individuos entre la segunda y la última medición, como lo evidencia una tendencia general de desaceleración del crecimiento cuando los juveniles se acercaron a los 11 meses de edad (Figura 2). Una prueba ANOVA de medidas repetidas evidenció (Tabla 3) diferencias significativas relacionadas tanto con la dieta experimental como con la fecha (edad) de la medición. Sin embargo, sólo en el caso de las dietas experimentales apareció una clara diferencia entre los grupos experimentales, con los individuos alimentados con Alimento B mostrando una TCT más alta

\section{Variance analysis of Individual Body Mass}

Individual weight was compared, considering as explanatory factors the period of experimentation and the different diets tested. This allowed us to establish significant differences between individuals(ANOVA, $\mathrm{df}=$ $5, P<0.001)$ conditioned by the diet and measuring time (initial vs. final).The proposed ANOVA model explained $87 \%$ of the variation $\left(\mathrm{R}^{2}\right)$. Estimation of the variance components shows that $83 \%$ of the variance is due to the age (day) at which individuals were measured rather than to the experimental groups. 

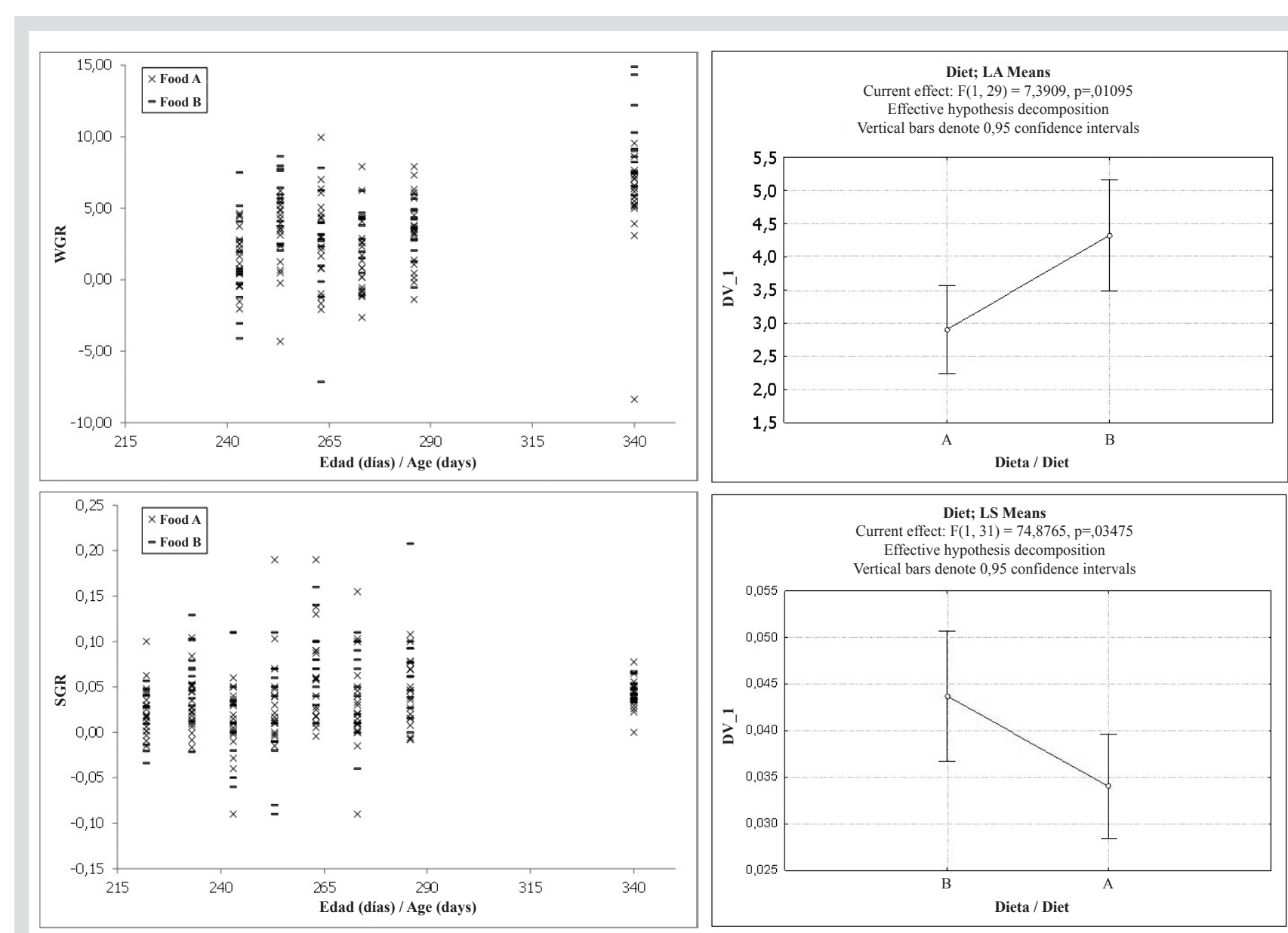

Figura 2. Tasas de crecimiento en tamaño (TCT) y peso (TCP) para dos grupos experimentales (Alimento A, n: 30 individuos; Alimento B, n: 13 individuos) de juveniles de tortuga carey alimentados con dietas comerciales.
Figure 2. Growth rates in size (SGR) and weight (WGR) for two experimental groups (Food A, n: 30 individuals; Food B, n: 13 individuals) of Hawksbill Turtle juveniles fed with commercial diets.
Las tasas de crecimiento en peso para los grupos experimentales presentaron valores entre 8.37 y $14.90 \mathrm{~g}$ día $^{-1}$, con distribución normal (Shapiro-Wilk $\mathrm{P}=0.987, P$ $=0.086$ ) con un valor promedio de $3.4 \pm 3.4 \mathrm{~g} \mathrm{día}^{-1}$. Los valores medios mostraron diferencias significativas entre los grupos (prueba $\mathrm{t}$, valor $\mathrm{t}=2.42, P=0.016, \mathrm{df}=193$ ), siendo más altos en el grupo alimentado con el Alimento B $\left(4.13 \pm 3.079 \mathrm{~g} \mathrm{día}^{-1}\right)$ que con el Alimento A $(2.92 \pm$ $3.079 \mathrm{~g} \mathrm{día}^{-1}$ ). Un ANOVA de medidas repetidas (Tabla 3) evidenció que tanto la dieta como la edad (es decir, la fecha en que se tomó la medición) de los individuos tuvieron un efecto en los valores de la TCP, aunque el efecto relacionado con la dieta fue menor. Los valores de la TCP no mostraron una tendencia general, excepto por un aumento general desde el momento en que finalizó el experimento y en el grupo completo de las tortugas que se alimentaron con proteína fresca.
Meanwhile, a contrast analysis of the weight differences between individuals showed that the mass for Food A specimens differed significantly from that of both those fed fish muscle and those fed Food B. From this point of view, the weight increase observed here was also influenced by differences in development due to individuals. At the end of the captivity period, the individuals presented an average size (SCLmax) and weight of $21.8 \pm 2.1 \mathrm{~cm}$ and $1255.61 \pm$ $323.72 \mathrm{~g}$, respectively (Table 4).

\section{DISCUSSION}

Hawksbill Turtles have a narrow and serrated beak that provides easy access to crevices, and are described as an opportunistic species that feeds on the epibiota of sponges and corals (Witzell, 1983). Although they have a strong preference for invertebrates (León and Bjorndal, 2002; Carrión et al., 2013), several studies based on stomach content analysis 
Tabla 3. Análisis de varianza de medidas repetidas para los valores de la TCT y TCP para dos grupos experimentales de tortugas carey alimentadas con dos dietas diferentes (A y B); las mediciones se realizaron en seis momentos diferentes (edad) durante casi los tres meses que duró el experimento.
Table 3. Repeated measures analysis of variance for SGR and WGR values for two experimental groups of Hawksbill Turtles fed two different diets (A and B), measured six different times (age) during almost three months of experiment.

\begin{tabular}{|c|c|c|c|c|c|}
\hline \multicolumn{6}{|l|}{ TCT / SGR } \\
\hline Efecto / Effect & SS & DF & SRA / MS & $\mathbf{F}$ & $\mathbf{P}$ \\
\hline Intercepto / Intercept & 0.381 & 1 & 0.381 & 313.22 & $<0.01$ \\
\hline Dieta / Diet & 0.006 & 1 & 0.006 & 4.88 & 0.035 \\
\hline Error / Error & 0.038 & 31 & 0.001 & & \\
\hline Años / Years & 0.077 & 7 & 0.011 & 6.45 & $<0.01$ \\
\hline Edad $*$ dieta / Age* diet & 0.015 & 7 & 0.002 & 1.29 & 0.26 \\
\hline Error / Error & 0.370 & 217 & 0.002 & & \\
\hline \multicolumn{6}{|l|}{ TCP / WGR } \\
\hline Efecto / Effect & SS & DF & SRA / MS & $\mathbf{F}$ & $\mathbf{P}$ \\
\hline Intercepto / Intercept & 2.308 .434 & 1 & 2.308 .434 & 192.82 & $<0.01$ \\
\hline Dieta / Diet & 88.481 & 1 & 88.481 & 7.39 & 0.011 \\
\hline Error / Error & 347.177 & 29 & 11.972 & & \\
\hline Años / Years & 588.721 & 5 & 117.744 & 19.10 & $<0.01$ \\
\hline Edad * dieta / Age* diet & 75.134 & 5 & 15.027 & 2.44 & 0.037 \\
\hline Error / Error & 893.913 & 145 & 6.165 & & \\
\hline
\end{tabular}

Análisis de varianza de la masa corporal individual

Se comparó el peso individual, considerando como factores explicativos el período de experimentación y las diferentes dietas probadas. Esto nos permitió establecer diferencias significativas entre los individuos (ANOVA, $\mathrm{df}=5, P<0.001$ ) condicionadas por la dieta y el tiempo de medición (inicial vs. final). El modelo de ANOVA propuesto explicó $87 \%$ de la variación $\left(\mathrm{R}^{2}\right)$. La estimación de los componentes de la varianza muestra que $83 \%$ de la varianza se debe a la edad (día) en que se midieron los individuos en lugar de a los grupos experimentales.

Mientras tanto, un análisis de contrastes de las diferencias de peso entre individuos mostró que la masa de los especímenes alimentados con el Alimento A difería significativamente de los que se alimentaban de músculo de pescado y Alimento B. Desde este punto de vista, el aumento de peso observado en este estudio también se vio influenciado por diferencias en el desarrollo debido a los individuos. Al final del período de cautiverio, los individuos presentaron un tamaño promedio (LRCmax) y un peso de $21.8 \pm 2.1 \mathrm{~cm}$ y $1255.61 \pm 323.72 \mathrm{~g}$, respectivamente (Tabla 4). show an abundance of macroalgae (Bell, 2013). Because of that, the Hawksbills are currently described primarily as a consumer of macroalgae and second as an omnivore. From this point of view, to replicate an optimal diet for captive post hatchlings-juveniles represents a challenge. In these stages, sea turtles are characterized by high protein and carbohydrate requirements (Pelegrín et al., 2003a; Bell, 2013).

Despite these constraints, the values of body size (16.3-26.8 cm SCL) and body mass (648.29-2221.95 g) obtained at the end of this study are similar to those obtained in previous studies for the maintenance of Hawksbill turtle posthatchlings. For example, Joya and Molina (2006) reported values of SCL between 22.5 and $24.9 \mathrm{~cm}$ and mass between $943.44 \mathrm{~g}$ and $1318.08 \mathrm{~g}$ for eleven-month-old individuals. Our results for SCL and mass extend beyond these ranges. This may be related to the greater number of individuals used in this study, which all originated from the same nest. Both elements could increase the heterogeneity in the sizes and mass of the specimens.

Gutierrez and Cabrera (1996) reported an average body mass of $1521 \pm 280 \mathrm{~g}$ and $1534 \pm 253 \mathrm{~g}$ and an SCL of $23.60 \pm 1.88 \mathrm{~cm}$ and $20.20 \pm 1.57 \mathrm{~cm}$ for two groups of 130 captive Hawksbill Turtle post-hatchlings (Table 2) at 11 months of age. SCL values are similar to those we obtained, but the mass is $>250 \mathrm{~g}$ higher. Gutierrez and Cabrera (1996) used a diet of fish muscle (Oreochromis sp.) throughout the head-start process. 
Tabla 4. Promedio de masa $(n=76)$ y tamaño de las tortugas carey juveniles utilizadas en este estudio para probar dos grupos experimentales de alimentos (Alimento A y Alimento B). La fase experimental se muestra en gris. : Media DE: desviación estándar.
Table 4. Average mass $(n=76)$ and size of juvenile Hawksbill Turtles used in this study to test two experimental (Food A and Food B).The experimental phase is shown in gray.: Mean. SD: standard deviation.

\begin{tabular}{|c|c|c|c|c|c|c|}
\hline \multicolumn{7}{|c|}{ Biomasa / Biomass (g) } \\
\hline & \multicolumn{2}{|c|}{ Alimento $\mathrm{A}(n=20) /$ Food $\mathrm{A}(n=20)$} & \multicolumn{2}{|c|}{ Alimento B $(n=13) /$ Food B $(n=13)$} & \multicolumn{2}{|c|}{ Músculo de pescado / Fish muscle $(n=43)$} \\
\hline Edad (días) / Age (days) & $\mathrm{X}$ & SD & $\mathrm{X}$ & SD & $\mathrm{X}$ & SD \\
\hline 233 & 506.98 & 85.89 & 668.30 & 81.39 & 581.31 & 104.53 \\
\hline 243 & 521.65 & 99.44 & 679.23 & 81.14 & 633.24 & 125.17 \\
\hline 253 & 537.66 & 121.54 & 733.23 & 90.24 & 667.69 & 135.94 \\
\hline 263 & 580.05 & 117.53 & 755.33 & 98.97 & 743.84 & 168.83 \\
\hline 273 & 592.93 & 118.14 & 800.49 & 112.01 & 812.23 & 204.80 \\
\hline 286 & 636.57 & 138.78 & 845.99 & 113.10 & 936.87 & 233.94 \\
\hline 340 & 980.59 & 182.18 & 1351.17 & 251.63 & 1352.76 & 325.77 \\
\hline \multicolumn{7}{|c|}{ Longitud recta del caparazón / Straight Carapace Length (cm) } \\
\hline 206 & 14.95 & 0.85 & 16.52 & 0.56 & 15.71 & 1.06 \\
\hline 222 & 15.33 & 1.05 & 16.82 & 0.79 & 15.88 & 1.02 \\
\hline 233 & 15.69 & 1.07 & 17.53 & 0.75 & 16.54 & 1.21 \\
\hline 243 & 15.81 & 1.05 & 17.68 & 0.83 & 16.72 & 1.35 \\
\hline 253 & 16.14 & 1.18 & 17.82 & 0.67 & 17.06 & 1.42 \\
\hline 263 & 16.73 & 1.42 & 18.62 & 0.66 & 17.97 & 1.65 \\
\hline 273 & 17.03 & 1.39 & 19.11 & 0.69 & 18.70 & 1.78 \\
\hline 286 & 17.58 & 1.59 & 20.00 & 1.01 & 19.20 & 1.89 \\
\hline 340 & 20.09 & 1.53 & 22.44 & 1.36 & 22.44 & 2.14 \\
\hline
\end{tabular}

\section{DISCUSIÓN}

Las tortugas carey tienen un pico estrecho y cerrado que proporciona fácil acceso a las grietas; son consideradas como una especie oportunista que se alimenta de la epibiota de esponjas y corales (Witzell, 1983). Aunque tienen una fuerte preferencia por los invertebrados (León y Bjorndal, 2002; Carrión et al., 2013), varios estudios basados en el análisis del contenido del estómago muestran abundancia de macroalgas (Bell, 2013). Debido a esto, las tortugas carey se describen hoy en día principalmente como especie consumidora de macroalgas, y segundo, como una omnívora. Desde este punto de vista, replicar una dieta óptima para las crías post-eclosión y los ejemplares juveniles en cautiverio representa un desafío. En estas etapas, las tortugas marinas se caracterizan por altos requerimientos de proteínas y carbohidratos (Pelegrín et al., 2003a; Bell, 2013).

A pesar de estas restricciones, los valores del tamaño corporal (16.3-26.8 cm LRC) y la masa corporal (648.29$2221.95 \mathrm{~g}$ ) obtenidos al final de este estudio son similares a los obtenidos en estudios previos para el mantenimiento
The use of diets based only on artificial feed, as in this study, led to a lesser body development (weight) and also had an effect on size growth rates. The range of SGR ( 0.01 and $\left.0.21 \mathrm{~cm} \mathrm{day}^{-1}\right)$ was lower than those obtained by Joya and Molina (2006) or Gutiérrez and Cabrera (1996). Our results are consistent with the observations made by Joya and Molina (2006), who concluded that a pellet made of animal protein can promote differences in growth rates and body condition. The values of WGR reported here are below those reported in other studies where individuals were fed with fresh protein and formulated supplements (See Table 2). Besides the lower growth rates obtained by the experimental diets we tested, significantly higher values were evident for both the SGR and the WGR obtained for individuals fed a pellet based on squid meal (Food B). This finding agrees with those of Pelegrín et al. (2006), who found that diets based on this source of protein promoted higher WGR values.

Further, we found that the maximum values of WGR (11.35 $\mathrm{g} \mathrm{day}^{-1}$ ) correspond to the values for 
de las crías de tortuga carey. Por ejemplo, Joya y Molina (2006) registraron valores de LRC entre 22.5 y $24.9 \mathrm{~cm}$ y una masa entre $943.44 \mathrm{~g}$ y $1318.08 \mathrm{~g}$ para los individuos de once meses. Los resultados de este trabajo para la LRC y masa sobrepasan tales rangos. Esto puede estar relacionado con el mayor número de individuos utilizados en este estudio, los cuales procedían del mismo nido. Ambos elementos podrían aumentar la heterogeneidad del tamaño y la masa de los especímenes.

Gutiérrez y Cabrera (1996) registraron una masa corporal promedio de $1521 \pm 280 \mathrm{~g}$ y $1534 \pm 253 \mathrm{~g}$ y un LRC de $23.60 \pm 1.88 \mathrm{~cm}$ y $20.20 \pm 1.57 \mathrm{~cm}$ para dos grupos de 130 juveniles de tortuga carey (Tabla 2) a los 11 meses de edad. Los valores de la LRC son similares a los obtenidos en este estudio, pero la masa es $>250$ g más alta. Gutiérrez y Cabrera (1996) usaron una dieta de músculo de pescado (Oreochromis sp.) durante todo el proceso de la cría en cautiverio.

El uso de dietas basadas solo en alimentos artificiales, como en este estudio, condujo a un menor desarrollo corporal (peso) y también tuvo un efecto en las tasas de crecimiento en tamaño. El ámbito de TCT $\left(0.01\right.$ y $\left.0.21 \mathrm{~cm} \mathrm{día}^{-1}\right)$ fue inferior al obtenido por Gutiérrez y Cabrera (1996) o Joya y Molina (2006). Nuestros resultados son consistentes con las observaciones realizadas por Joya y Molina (2006), quienes concluyeron que un pellet hecho de proteína animal puede promover diferencias en las tasas de crecimiento y la condición corporal de los individuos. Los valores de la TCP registrados en nuestro estudio están por debajo de los de otros estudios donde los individuos fueron alimentados con proteína fresca y suplementos formulados (consulte la Tabla 2). Además de valores en tasas de crecimiento más bajos obtenidas por las dietas experimentales que se probaron en este estudio, se observaron valores significativamente más altos tanto para la TCT como para la TCP obtenidas para los individuos alimentados con pellets basados en harina de calamar (alimento B). Este hallazgo concuerda con las estimaciones de Pelegrín et al. (2006), quienes encontraron que las dietas basadas en esta fuente de proteína promovían valores más altos de TCP.

Además, se encontró que los valores máximos de la TCP (11.35 $\left.\mathrm{g} \mathrm{día}^{-1}\right)$ corresponden a aquellos individuos alimentados con proteína fresca. Este hallazgo concuerda con los resultados registrados por Gutiérrez y Cabrera (1996), quienes evidenciaron que la alimentación con proteína fresca incrementa el desarrollo corporal (masa) de las tortugas cautivas. Cuando los individuos son alimentados con proteína fresca después de un largo período de consumir alimentos individuals fed fresh protein. This finding agrees with the results reported by Gutiérrez and Cabrera (1996), who gave evidence that feeding with fresh protein increased the body development (mass) of captive turtles. When individuals are fed with fresh protein after a long period of artificial meals, they respond by over increasing their consumption, which promotes higher and faster growth rates.

The quantity of Food A and Food B consumed was influenced by the visibility in the water column, which depended on the frequency of the maintenance of the tanks. Eventually, when the visibility inside the tank was reduced after two or three days of not changing the water caused by logistical limitations or maintenance of the reservoir system, the turtles did not eat and showed increased stress and aggressiveness.

The level of food consumption is also influenced by each individual's access to food; this in turn depends on how much it competes with others or the risks it faces to acquire it. In the case of sea turtles, individual size apparently influences the growth of individuals and indirectly impacts the age at which they reach reproductive maturity (Bjorndal et al., 2013a). The smallest individuals in a group grow at a slower rate not only because they are genetically predisposed to do so but also because their body condition limits their ability to access food. Bjorndal et al. (2013a) described this situation by comparing growth rate and size at maturity in captive C. mydas in Cayman Islands. This could explain why the body mass differences obtained between the experimental groups in this study were better explained by the specimens than by the provided diet. From this point of view, new approaches that assess individual assimilation are required, but they should also consider the competition among individuals for food and the energy costs associated with the process of eating.

Shaw et al. (1989) drew attention to the need for caution in the exclusive use of commercial foods in the maintenance of sea turtles. They argued that the use of products derived from soybeans as a protein source in many of these formulations poses risks to the health of reptiles due to high concentrations of phytoestrogens, genistein and diadzein. These compounds present progressive accumulation, and the activity in the bloodstream can cause liver disorders, depression of the pituitary gland, or alterations in sexual development. Joya and Molina (2006) reported lower efficiency using a pellet based 
artificiales, responden aumentando excesivamente su consumo, lo que promueve tasas de crecimiento más altas y rápidas.

De otro lado, la cantidad de alimento A y alimento B consumida por las tortugas se vio influenciada por la visibilidad en la columna de agua, lo que dependía de la frecuencia de mantenimiento de los tanques. Cuando la visibilidad dentro del tanque se reducía al mínimo, después de dos o tres días de no cambiar el agua a consecuencia de las limitaciones logísticas o de mantenimiento del sistema de reservorio, las tortugas no comieron y mostraron mayor estrés y agresividad.

El nivel de consumo de alimentos también está influenciado por el acceso de cada individuo a los alimentos; esto a su vez depende de cuánto compita con otros o de los riesgos a que ha de enfrentarse para adquirirlo. En el caso de las tortugas marinas, el tamaño individual influye aparentemente en el crecimiento de los individuos y tiene un efecto indirecto en la edad a la que alcanzan la madurez reproductiva (Bjorndal et al., 2013a). Los individuos más pequeños de un grupo crecen a un ritmo más lento, no sólo porque están genéticamente predispuestos a hacerlo, sino también porque su condición corporal limita su capacidad para acceder a los alimentos. Bjorndal et al. (2013a) describieron esta situación comparando la tasa de crecimiento y la talla de madurez sexual en ejemplares de $C$. mydas en cautiverio en las islas Caimán. Esto podría explicar por qué las diferencias de masa corporal obtenidas en los grupos experimentales de este estudio fueron mejor explicadas por los especímenes que por la dieta proporcionada. Desde este punto de vista, se requieren nuevos enfoques que evalúen la asimilación individual, pero también que consideren la competencia entre los individuos por los alimentos y los costos de energía asociados con el proceso de alimentación.

Shaw et al. (1989) llamaron la atención sobre la necesidad de tener precaución en el uso exclusivo de alimentos comerciales para el mantenimiento de las tortugas marinas. Argumentaron que el uso de productos derivados de la soya como fuente de proteínas en muchas de estas formulaciones plantea riesgos para la salud de los reptiles debido a las altas concentraciones de fitoestrógenos, genisteína y diadzeína. Estos compuestos presentan una acumulación progresiva, y la actividad en el torrente sanguíneo, lo que puede causar trastornos hepáticos, depresión de la glándula pituitaria o alteraciones en el desarrollo sexual. Joya y Molina (2006) registraron una menor eficiencia al utilizar un pellet basado en un compuesto derivado de esta oleaginosa; sus resultados mostraron una menor palatabilidad de los alimentos y on such an oleaginous compound; their results showed lower food palatability and digestibility difficulties for some of its components. Here, it should be noted that although both tested foods have ingredients derived from soy, they are not the basis of its composition. Thus, it is presumed that soy does not represent a risk. Then, there is no evidence linking the results obtained with the presence of soy flour in the composition of foods we tested. However, there are studies that give evidence of a positive effect of soy use for the maintenance of reptiles. Zhou et al. (2016) reported that the replacement of $30 \%$ of fresh meal by soybean protein concentrate is feasible if always accompanied by the adhesion of phosphatase enzyme (phytase).

The selection of a food should consider the potential palatability of the diet for the species of interest, which depends not only on its composition but also on the assimilation of nutrients by individuals both individually and in combination with other foods (Espinosa y Labarta, 1987). For artificial foods used for marine turtles, there are no estimations regarding the factors that might influence the palatability of artificial foods, which makes palatability a relevant topic to consider in future studies. Based on our results, conservation programs that might consider captive maintenance of juveniles or post hatchlings sea turtles, must evaluate the response of turtles to artificial foods at earlier life stages, and before including items of high preference for these species, as shrimp or fish muscle, in their diet.

Diets based exclusively on processed foods should consider the composition of such mixtures (protein concentrations should be above $40 \%$ ) and the associated logistics and economic costs. In economic terms, in March 2007, Food A cost COP $\$ 1,997.5$ (US\$ 0.79) per kilogram, while Food B cost COP $\$ 2,300$ (US\$ 0.91) per kilogram. Maintaining a weekly consumption of 250 $\mathrm{g}$ /individual for a group of 100 six-month-old turtles would cost less than COP $\$ 500 /$ week (US\$ $0.2 /$ week). Approximately $18 \mathrm{~kg}$ of fish muscle would be needed to feed 100 six-month-old turtles for a week, which would cost COP \$25,000/week (US\$ 9.94/week), far more than the cost of the pellets. Also, the palatability for and avidity of the species of interest must be evaluated at the time that the food is offered to the individuals. Based on our results, artificial foods we tested are not adequate to be exclusive diets for E. imbricata hatchlings. However, the presence of amino acids and vitamins in these 
dificultades de digestibilidad para algunos de sus componentes. Se debe tener en cuenta aquí que, aunque los alimentos probados en este ensayo tenían ingredientes derivados de la soya, ésta no es la base de su composición. Desde este punto de vista, se presume que la soya no representaba un riesgo para la salud de las tortugas; además, no existen evidencias que relacionen los resultados obtenidos con la presencia de harina de soya en la composición de los alimentos probados en este estudio. Sin embargo, hay estudios que evidencian un efecto positivo del uso de la soya para el mantenimiento de los reptiles. Zhou et al. (2016) registraron que la sustitución del $30 \%$ de la comida fresca por un concentrado de proteína de soya es factible, siempre que en todo momento se le añade la enzima fosfatasa (fitasa).

La selección de un alimento debe considerar la posible palatabilidad de la dieta para las especies de interés, que depende no solo de su composición sino también de la asimilación de nutrientes por parte de los individuos, tanto de forma individual como en combinación con otros alimentos (Espinosa y Labarta, 1987). Para los alimentos artificiales utilizados para las tortugas marinas, no hay estimaciones con respecto a los factores que podrían influir en la palatabilidad de los alimentos artificiales, lo que hace que la palatabilidad deba considerarse en estudios futuros. Con base en estos resultados, los programas de conservación que puedan considerar el mantenimiento en cautiverio de juveniles o crías post-eclosión de tortugas marinas, deben evaluar la respuesta de los animales a los alimentos artificiales en las etapas tempranas, e incluir en su dieta elementos de alta preferencia para estas especies, como camarón o músculo de pescado.

Las dietas basadas exclusivamente en alimentos procesados deben considerar la composición de dichas mezclas (concentraciones de proteína superiores a $40 \%$ ) y los costos logísticos y económicos asociados. En términos económicos, en marzo de 2007, el Alimento A costaba COP \$ 1997.5 (US \$ 0.79) por kilogramo, mientras que el Alimento B costaba COP $\$ 2300$ (US \$ 0.91) por kilogramo. Mantener un consumo semanal de $250 \mathrm{~g}$ /individuo para un grupo de 100 tortugas de seis meses costaría menos de COP $\$ 500 /$ semana (US \$ 0.2 / semana). Se necesitarían aproximadamente $18 \mathrm{~kg}$ de músculo de pescado para alimentar a 100 tortugas de seis meses durante una semana, lo que costaría aproximadamente COP \$25000/ semana (US \$ 9.94/semana), mucho más que el costo de los pellets. Además, la palatabilidad de los alimentos y la avidez por los mismos de las especies de interés deben evaluarse en el momento en que se ofrece el alimento a los individuos. Según nuestros resultados, los alimentos artificiales que probamos no compounds, and their low cost, can make them viable as a supplementary item for turtles, especially if the foods are based on over $40 \%$ of animal protein and include squid meal in their composition. Therefore, there is a need for the execution of new projects measuring the effects of diets composed of different mixtures of fresh meals and artificial foods, or applied at different ages, on the growth and physiology of captive sea turtles.

\section{ACKNOWLEDGMENTS}

This study was part of the project "Conservación de Tortugas Marinas Parque Tayrona", supported by PETROBRAS Unlimited Colombia, Acuario Mundo Marino, Universidad de Bogotá Jorge Tadeo Lozano (Santa Marta Campus), and the Unidad Administrativa Especial de Parques Nacionales Naturales of the Colombian government. The study was part of the activities of Programa de Conservación de Tortugas Marinas (ProCTM), Grupo de Investigación Dinámica y Manejo de Ecosistemas Marino-Costeros (DIMARCO)-UJTL during 2006-2007. We acknowledge the support and participation of all the technical staff and volunteers involved, especially María P. Molina, Catalina Ospina, Juan Manuel Rodriguez Baron, and Paola Saenz, whose efforts made this possible. We also would like to several anonymous reviewers for their comments and suggestions, which improved the presentation of this manuscript. All procedures of animal manipulation were submitted and approved by the Director Committee of the project "Caracterización de las Playas de Anidamiento del Parque Nacional Natural Tayrona - Caribe Colombiano, e Implementación de Estrategias de Manejo y Conservación para las Tortugas Marinas" conducted by Universidad de Bogotá Jorge Tadeo Lozano and Parques Nacionales Naturales de Colombia during 2006-2008. 
son adecuados para utilizarse como dietas exclusivas para las crías de E. imbricata. Sin embargo, la presencia de aminoácidos y vitaminas en estos compuestos, y su bajo costo, pueden hacerlos viables como un elemento complementario para las tortugas, especialmente si los alimentos incluyen más de $40 \%$ de proteína animal y harina de calamar en su composición. Por lo tanto, existe la necesidad de ejecutar nuevos estudios que midan los efectos de las dietas compuestas de diferentes mezclas de comidas frescas y artificiales, o aplicadas a diferentes edades, sobre el crecimiento y la fisiología de las tortugas marinas en cautiverio.

\section{AGRADECIMIENTOS}

Este estudio formó parte del proyecto "Conservación de Tortugas Marinas del Parque Tayrona", apoyado por PETROBRAS Unlimited Colombia, Acuario Mundo Marino, Universidad de Bogotá Jorge Tadeo Lozano (UJTL) (Campus de Santa Marta) y la Unidad Administrativa Especial de Parques Nacionales Naturales del gobierno de Colombia. Así mismo, fue parte de las actividades del Programa de Conservación de Tortugas Marinas (ProCTM), Grupo de Investigación Dinámica y Manejo de Ecosistemas MarinoCosteros (DIMARCO) -UJTL durante 2006-2007. Se reconoce el apoyo y la participación de todo el personal técnico y los voluntarios involucrados, especialmente María P. Molina, Catalina Ospina, Juan Manuel Rodríguez Barón y Paola Saénz, cuyos esfuerzos hicieron posible el desarrollo de este estudio. Se agradece a varios revisores anónimos por sus comentarios y sugerencias, que ayudaron a mejorar la presentación de este manuscrito. Todos los procedimientos de manipulación de animales fueron presentados y aprobados por el Comité Directivo del proyecto "Caracterización de las Playas de Anidamiento del Parque Nacional Natural Tayrona - Caribe Colombiano, e Implementación de Estrategias de Manejo y Conservación para las Tortugas Marinas" llevado a cabo por la UJTL y Parques Nacionales Naturales de Colombia en 2006-2008. 


\section{BIBLIOGRAFÍA / LITERATURE CITED}

Adey, W.H. and K. Loveland. 2007. Dynamic aquaria: building living ecosystems. Academic Press. Washington, D.C. 528 p.

Bailey, T. 2008. Mortality at a Hawksbill Turtle (Eretmochelys Imbricata) rearing center. Wildlife Middle East News, 3:2

Bell, I. 2013. Algivory in Hawksbill Turtles: Eretmochelys imbricata food selection within a foraging area on the Northern Great Barrier Reef. Mar. Ecol., 34:43-55.

Bjorndal, K., J. Parsons, W. Mustin and A. Bolten. 2013a. Threshold to maturity in a long-lived reptile: interactions of age, size, and growth. Mar. Biol., 160: $607-616$

Bjorndal, K., B. Schroeder, A. Foley, B. Witherington, M. Bresette, D. Clark, R. Herren, M. Arendt, J. Schmid, A. Meylan, P. Meylan, J. Provancha, K. Hart, M. Lamont, R. Carthy and A. Bolten. 2013b. Temporal, spatial, and body size effects on growth rates of Loggerhead Sea Turtles (Caretta caretta) in the Northwest Atlantic. Mar. Biol., 160(10): 2711-2721.

Bolten, A. 1999.Techniques for measuring sea turtles. 1-10. In: Eckert, K.L., K. Bjorndal, A. Abreu-Grobois and M. Donnelly (Eds.). Research and Management Techniques for the Conservation of Sea Turtles. IUCN/SSC Marine Turtle Specialist Group Publ., Washington. 248 p.

Burke, R.L. 2015. Head-starting turtles: learning from experience. Herpetol. Conserv. Biol., 10 (Symposium): 299-308.

Carrión, J., C. Canales-Cerro, R. Arauz and R. Riosmena-Rodríguez. 2013. Habitat use and diet of juvenile Eastern Pacific Hawksbill Turtles (Eretmochelys imbricata) in the North Pacific coast of Costa Rica. Chelonian Conserv. Biol., 12: 235-245.

Casale, P., A.D. Mazaris, D. Freggi, C. Vallini and R. Argano. 2009. Growth rates and age at adult size of Loggerhead Sea Turtles (Caretta caretta) in the Mediterranean Sea, estimated through capture-mark-recapture records. Sci. Mar., 73: 589-595.

Chuen-Im, T., M. Areekijseree, S. Chongthammakun and S.V. Graham. 2010. Aerobic Bacterial Infections in Captive Juvenile Green Turtles (Chelonia mydas) and Hawksbill Turtles (Eretmochelys imbricata) from Thailand. Chel. Conserv. Biol., 9:135-142.

Endres, C. S. and K. J. Lohmann. 2012. Perception of dimethyl sulfide (DMS) by loggerhead sea turtles: a possible mechanism for locating high-productivity oceanic regions for foraging. J. Exp. Biol., 215: 3535-3538.

Espinosa de los Monteros, J. y U. Labarta. 1987. Alimentación en acuicultura. Plan de Formación de Técnicos Superiores en Acuicultura. Comisión Asesora de Investigación Técnica y Científica, Madrid. 325 p.

Franco-Herrera,A. 2005. El Rodadero, más que un centro turístico en el Caribe colombiano. Una aproximación a la oceanografía de la Ensenada de Gaira. Universidad de Bogotá Jorge Tadeo Lozano, Santa Marta. 58 p.

Gutiérrez, W. and J.C. Cabrera. 1996. Growth, food conversion and mortality of Eretmochelys imbricata (Reptilia: Chelonidae) in artificial ponds (Costa Rica). Rev. Biol. Trop., 44: 847-851.

Harewood, A. and J. Horrocks. 2008. Impacts of coastal development on Hawksbill hatchling survival and swimming success during the initial offshore migration. Biol. Conserv., 141: 394-401.

Harfush, M., C. Martínez, E. López and C. Rojas. 2000. Advances in the determination of dietary protein requirements for ad libitum fed Lepidochelys olivacea hatchlings. 313. In: Abreu-Grobois F.A., R. Briseño-Dueñas, R. Márquez-Millán and L. Sarti-Martínez (Eds.). 18th. Annual Symposium on Sea Turtle Biology and Conservation, Mazatlán, Sinaloa, México. U.S. Department of Commerce, National Oceanic and Atmospheric Administration, National Marine Fisheries Service, Southeast Fisheries Science Center.

Joya, M. y M.P. Molina. 2006. Levante de neonatos de tortuga carey Eretmochelys imbricata (Linnaeus, 1766) mediante la implementación de dos tipos de dietas en el Acuario Mundo Marino, Santa Marta. B.Sc. Thesis. Universidad Jorge Tadeo Lozano, Bogotá.111 p.

Kakizoe, Y., K. Sakaoka, Y. Akune, Y. Kanou, T. Saito and I. Uchida. 2013. Change of plasma chemistry values in captive breeding turtles (Caretta caretta). ISRN Zoology. 1-7.

Kanghae, H., K. Thongprajukaew, A. Madlee and K. Kittiwattanawong. 2014. Is artificial feed suitable for juvenile Green Turtles (Chelonia mydas)? Aquaculture, 428-429: 97-103.

Kaufmann, R. 1975. Observaciones sobre el crecimiento de tortugas marinas en cautividad. Caldasia, 11:139-150.

Kellems, R.O. and D.C. Church. 2002. Livestock feeds and feeding. $5^{\text {th }}$ ed. Prentice Hall, New Jersey. 705 p.

Kilic, C. and O. Candan. 2014. Hatchling sex ratio, body weight and nest parameters for Chelonia mydas nesting on Sugozu beaches (Turkey). Anim. Biodiv. Conserv., 37: 177-182.

Labrada-Martagón, V., L.C. Méndez-Rodríguez, S.C. Gardner, V.H. Cruz-Escalona and T. Zenteno-Savín. 2010. Health indices of the Green Turtle (Chelonia mydas) along the Pacific coast of Baja California Sur, Mexico: II. Body condition index. Chelonian Conserv. Biol., 9: 173-183.

León, Y.M. and K.A. Bjorndal. 2002. Selective feeding in the Hawksbill Turtle, an important predator in coral reef ecosystems. Mar. Ecol. Prog. Ser., 245: 249-258.

Mann, M., R. Mellgreen, A. Arenas and A. Amiano. 2000a. Growth and behavior during the first year of life in two species of sea turtles. 227-229. In: Abreu-Grobois, F.A., R. Briceño-Dueñas, R. Márquez and L. Sarti (Eds.). Proc. $18^{\text {th }}$ An. Symp. Sea Turtle Biol. Cons. NOAA Tech. Mem., NMFS- 
SEFSC-436.Miami.

Mann, M., R. Mellgren, R. Figuero, C. Aguilar-Cardozo, J. Martínez-Aguilar and M. Coba-Ríos. 2000b. Diet dependent growth in Green sea turtle hatchlings . 291. In: Kalb H.J. and T. Wibbels (Eds.). Proc. $1^{\text {th }}$ An. Symp. Sea Turtle Biol. Cons. NOAA Tech. Memo., NMFS-SEFSC-443.Miami.

McClenachan, L., J.B. Jackson and M. Newman. 2006. Conservation implications of historic sea turtle nesting beach loss. Front. Ecol. Environ., 4: $290-296$. Meylan, A.B. 1999. Status of the Hawksbill Turtle (Eretmochelys imbricata) in the Caribbean Region. Chelonian Conserv. Biol., 3: $177-184$.

Moein, S., R. Mellgren and J.A. Musick. 2003. Visual acuity of juvenile Loggerhead Sea Turtles (Caretta caretta): A behavioral approach. Int. J. Comp. Psych., 116: 143-155.

Monterrosa, M.C. and M.F. Salazar. 2005. Levante de neonatos de Caretta caretta (Linnaeus, 1758) y su proceso de adaptación al medio natural, Santa Marta, Colombia. B.Sc. Thesis, Universidad de Bogotá Jorge Tadeo Lozano. Bogotá. 196 p.

Mortimer, J.A. 1995a. Headstarting as a management tool. 613-615. In: Bjorndal, K.A. (Ed.). Biology and conservation of sea turtles. Smithsonian Institution Press, Washington. 615 p.

Mortimer, J.A. 1995b. Feeding ecology of sea turtles. 103-109 In: Bjorndal, K.A. (Ed.). Biology and conservation of sea turtles. Smithsonian Institution Press, Washington. 615 p.

Mortimer, J.A. 1999. Reducing threats to eggs and hatchlings: hatcheries. 175-178. In: Eckert, K.L., K. Bjorndal, A. Abreu-Grobois and M. Donnelly (Eds.). Research and management techniques for the conservation of sea turtles. IUCN/SSC Marine Turtle Specialist Group Publ., 4. Washington. 248 p.

Mortimer, J.A. and M. Donnelly 2008. Eretmochelys imbricata. IUCN SSC Marine Turtle Specialist Group. The IUCN Red List of Threatened Species 2008: e.T8005A12881238.http://dx.doi.org/10.2305/IUCN.UK.2008.RLTS.T8005A12881238.en. 16/07/2016.

Nagelkerken, I., L. Pors and P. Hoetjes. 2003. Swimming behavior and dispersal patterns of headstarted loggerhead turtles Caretta caretta. Aquat. Ecol., 37: $183-190$.

Okuyama, J., T. Shimizu, O. Abe, K. Yoseda and N. Arai. 2010. Wild versus head-started Hawksbill Turtles Eretmochelys imbricata: post-release behavior and feeding adaptions. Endanger. Species Res., 10: 181-190.

Pabón-Aldana, K., C.L. Noriega-Hoyos and G.A. Jaúregui. 2012. First satellite track of a head-started juvenile Hawksbill in the Colombian Caribbean. Mar. Turt. Newsl., 133: 4-7.

Pelegrín, E. and I. Fraga. 2002. Breeding of Hawksbill Turtle Eretmochelys imbricata with artificial food. 185-187. In: Mosier, A., A. Foley and B. Brost (Eds.). Proc. 20th An. Symp. Sea Turtle Biol. Cons. NOAA Techn. Mem. NMFS-SEFSC-477. Miami.

Pelegrín, E., S. Álvarez, I. Fraga y J. Galindo. 2003a. Requerimientos de proteína en sub juveniles de Tortuga Carey (Eretmochelys imbricata). II Congr. Iberoam. Virtual Acuic., 978-985.

Pelegrín, E., I. Fraga, J. Galindo, S. Álvarez, G. Nodarse and Y. Cruz. 2003b. Lipids requirements of Hawksbill Turtle hatchlings (Eretmochelys imbricata): 283. In Proc. 23rd An. Symp. Sea Turtle Biol. Cons. Pilcher, N. (Ed.). NOAA Techn. Mem. NMFS-SEFSC-536. Miami.

Pelegrín,E., S. Álvarez, J. Galindo y E. Regueira. 2006. Evaluación de la harina de calamar en dietas para juveniles de tortuga carey (Eretmochelys imbricata): 9. IV Congr. Iberoam. Virtual Acuic. 189-197

Ross, J.P. 1999. Ranching and captive breeding sea turtles: Evaluation as a conservation strategy. 197-199. In: Eckert, K.L., K. Bjorndal, A. Abreu-Grobois and M. Donnelly (Eds.). Research and management techniques for the conservation of sea turtles. IUCN/SSC Marine Turtle Specialist Group Publ., 4. Washington. 248p.

Sampson, L., A. Giraldo, L. Payán, D. Amorocho, T. Eguchi and J. Seminoff. 2015. Somatic growth of juvenile Green Turtle (Chelonia mydas) morphotypes in the Colombian Pacific. Mar. Biol., 162: 1559-1566.

Shaw, S., R. Willit, P. Lutz and G. Bossart. 1989. Possible effects of artificial foods on sea turtle health: 232-306. In Eckert S.A., K.L. Eckert and T.H. Richardson (Eds). Proc. $9^{\text {th }}$ An. Symp. Sea Turtle Biol. Cons. NOAA Tech. Mem., NMFS-SEFC-232. Miami.

Sison, T., M. Padilla, M. Vizmanos and M. Follosco. 1990. Isolation and identification of fungi found in necrotic skin lesions of captive marine turtles (Eretmochelys imbricata). Philippine J. Vet. Medic., 27(2): 35-36.

Tacon, A.G. 1989. Nutrición y alimentación de peces y camarones cultivados. Manual de capacitación.

Witzell, W.N. (Ed). 1983. Synopsis of biological data on the Hawksbill Turtle, Eretmochelys imbricata (Linnaeus, 1766). 137. FAO. Miami. 86 p.

Wood, J.R. and F.E. Wood.1979. Artificial incubation of green sea turtle eggs (Chelonia mydas). Proc. World Mar. Soc., 10: 215-221.

Wood, J.R. and F.E. Wood. 1981. Growth and digestibility for the Green Turtle (Chelonia mydas) fed diets containing varying protein levels. Aquaculture, 25: 269-274.

Wyneken, J., K.J. Lohmann and J.A. Musick (Eds). 2013. The biology of sea turtles. 3. CRC Mar. Biol. Ser. Taylor and Francis. 457 p.

Zhou, F., Y.Q. Wang, X.Y. Ding, W.K. Ng, F. He and H-L.Xue. 2016. Partial replacement of fish meal by soy protein concentrates in diets for a new Japanese strain of juvenile soft-shelled turtle, Pelodiscus sinensis. Aquac. Res., 47: 875-886. 